\title{
Malaria Parasite Survival Depends on Conserved Binding Peptides' Critical Biological Functions
}

\author{
Manuel E. Patarroyo1,2*, Gabriela Arévalo-Pinzón ${ }^{1,3}$, \\ Cesar Reyes ${ }^{1}$, Armando Moreno-Vranich ${ }^{1}$ and Manuel \\ A. Patarroyo ${ }^{1,3}$ \\ ${ }^{1}$ Fundación Instituto de Inmunología de Colombia FIDIC, \\ Bogotá, Colombia \\ 2Universidad Nacional de Colombia, Bogotá, Colombia \\ 3 Universidad del Rosario, Bogotá, Colombia \\ *Corresponding author: mepatarr@gmail.com
}

http://dx.doi.org/10.21775/cimb.018.057

Dedicated to the memory of Professors Henry G. Kunkel and Bruce Merrifield (Rockefeller University) and Peter Perlmann (Stockholm University) who introduced us to the fascinating worlds of immunology, peptide chemistry and malaria, respectively.

\begin{abstract}
Biochemical, structural and single amino acid level analysis of 49 Plasmodium falciparum protein regions (13 sporozoite and 36 merozoite proteins) has highlighted the functional role of each conserved high activity binding peptide (cHABP) in cell host-microbe interaction, involving biological functions such as gliding motility, traversal activity, binding invasion, reproduction, nutrient ion transport and the development of severe malaria. Each protein's key function in the malaria parasite's asexual lifecycle (pre-erythrocyte and erythro-cyte) is described in terms of cHABPs; their sequences were located in elegant work published by other groups regarding critical binding regions implicated in malarial parasite invasion. Such cHABPs represent the starting point for developing a logical and rational methodology for selecting an appropriate mixture of modified cHABPs to be used in a completely effective, synthetic antimalarial vaccine. Such methodology could be used for developing vaccines against diseases scourging humanity.
\end{abstract}

\section{Introduction}

One of the most relevant conserved functions for successful cell host-microbe interaction and parasite survival is binding to host cell molecules to mediate parasite invasion and multiplication.

Transcriptome analysis of $P$. falciparum has shown that $\sim 50$ of the $\sim 5,600$ proteins are directly involved in merozoite (Mrz) invasion of red blood cells (RBC) (Bozdech et al., 2003) and $\sim 30$ are involved in sporozoite (Spz) invasion of liver cells (Kaiser et al., 2004; Lasonder et al., 2008); however, only those undoubtedly shown to be on Spz and Mrz surface and/or directly mediating host-cell microbe functional interactions their relevant cHABPs will be analysed here. These represent the Achilles' heel of the $P$. falciparum malaria parasite (Patarroyo et al., 2015a).

A very robust, sensitive, specific synthetic peptide methodology, involving the Plasmodium falciparum parasite (infecting $\sim 200$ million people and killing $\sim 584,000$ of them annually) (World Health Orgaanization, 2014) as our leading, model disease for vaccine development has been thoroughly used for identifying $\sim 300$ cHABPs in this parasite's most relevant molecules for Spz binding to and invasion of liver cells (Garcia et al., 2006) and Mrz binding to and invasion of erythrocytes, and binding to endothelial cells (Rodriguez et al., 2008).

cHABPs become excellent candidate components for a minimal subunit based, multi-epitope, multistage, chemically-synthesised antimalarial vaccine when properly modified (mHABPs) (Patarroyo et al., 2011; Patarroyo et al., 2005; Patarroyo and Patarroyo, 2008), since blocking or destroying their biological functions may represent one of the most effective methods for impeding functions or killing the parasite

The aforementioned cHABPs are shown here at single amino acid and/or atomic level (when their 3Dstructure is available), representing the first attempt at comprehensively describing cell-host-microbe interactions at the deepest level, particularly regarding the $P$. falciparum parasite. Exquisite, relevant, biological functions have not yet been determined for a few of these cHABPs; however, it is hoped that they will be so in the near future, similar to what occurred during the last 25 years after the first cHABPs were identified (Calvo et al., 1991) based on the recognition that some SPf66 peptides (first chemicallysynthesised, anti-malarial vaccine developed by us 28 years ago) strongly and specifically bound to RBCs (Calvo et al., 1991; Patarroyo et al., 1988; Patarroyo et al., 1987).

Our institute has led research into two different, complementary directions aimed at developing a logical and rational methodology for a minimal subunit-based, multiepitope, multistage, fully and completely protective antimalaria vaccine and defining physicochemical and immunological principles for vaccine development: a functional biological approach (here deeply analysed) for identifying important regions of the most relevant molecules involved in $P$. falciparum malaria invasion and infection and their biological functions and a simultaneous immunochemical-immunogenetic approach to render these cHABPs into highly immunogenic, protection-inducing components (beyond the scope of this manuscript, but deeply analysed and reviewed in Patarroyo et al., 2015b; Patarroyo et al., 2011). 


\section{The functional biological approach}

Differently to a purely immunological approach based on large sero-epidemiological information suggesting that the most significant and relevant molecules for vaccine development were highly antigenic or immunogenic ones and highly variable (thousands of genetic variants being present in the $P$. falciparum genome) as a mechanism for escaping immune pressure, we suggested 25 years ago that the most relevant fragments or amino acid sequences to be included in a vaccine should be those directly involved in biological functions like invasion, infection and some other critical biological functions and that a deep analysis (at the atomic level if possible) of this very complex parasite should be performed during this parasite's different functionally invasive stages. We predicted that specific receptor-ligand interactions could lead to a deep understanding of this parasite's biology and the pertinent physicochemical rules and that such understanding could lead to a logical and rational methodology for vaccine development, the raison d'être of this manuscript.

Conserved binding sequences or cHABPs have been confirmed after a deep analysis of all amino acids sequences from the proteins described here which have been derived from different $P$. falciparum strains and isolates deposited in the National Center for Biotechnology Information (NCBI), cHABPs (by definition) only being those not showing any amino acid sequence variation in all strains or the few displaying one variation 1 or 2 residues downstream the $\mathrm{N}$-terminus or upstream the $\mathrm{C}$-terminus. The rationale being that since these cHABPs are 20 mer long they can be shortened or extended 1 or 2 residues to exclude variable residues for mHABP design without dramatically modifying or changing these peptides' $3 D$ structure.

\section{The sporozoites' journey to the liver Spz-derived cHABPs perform different biological functions}

\section{Gliding motility and Spz displacement}

Once under the skin (where they can stay for $\sim 60$ minutes), the 100-1,000 Spz (Figure 1A) inoculated during an Anopheles mosquito bite begin their journey (Vaughan et al., 2008). They move at $\sim 2-4 \mu \mathrm{m} / \mathrm{second}$ (Amino et al., 2008) (Figure 1B) with characteristic slip-stick displacement movements (gliding motility) modulated by the turnover of discrete adhesion sites (Munter et al., 2009). Such movement is mediated by a set of proteins, such as thrombospondin-related anonymous protein (TRAP) (Sultan et al., 1997) and TRAP-like protein (TLP) (Moreira et al., 2008), secreted by the micronemes at the Spz apical pole (Figures $1 \mathrm{~A}$ and $1 \mathrm{C}$ ) and translocated to the membrane, together with the membrane coat multifunctional circumsporozoite protein 1 (CSP-1) (Figure 1D and Figure 2A), prior to hepatocyte invasion.

Note: From here on Figure 2 shows all molecules' PlasmoDB code numbers, molecular weight, relative size and CHABP location and Table 1 shows CHABP amino acid sequences, with their initial and last amino acid numbers.
Only critical residues whose biological functions have been clearly determined (in bold) will be mentioned in the text (location number as superscript to the left).

TRAP is a $63 \mathrm{kDa}$ type I microneme protein which is essential for $\mathrm{Spz}$ gliding motility conserved in all Plasmodium species (Sultan et al., 1997); it has an acidic C-terminal cytoplasmic tail, a transmembrane region and four extracellular domains: a proline-rich region, a hypervariable region, a thrombospondin-type-related region 1 (TSR) and a 200 amino acid-long von Willebrand factor Alike (vWA) domain (Figure 1D and 2A) (Rogers et al., 1992).

cHABP 3271 is contained in vWA domain (involved in cellcell, cell-matrix, matrix-matrix interactions); such domain includes a metal-ion dependent adhesion site (MIDAS) where cHABP $32711^{162} \mathrm{D},{ }^{167} \mathrm{~S},{ }^{170} \mathrm{D}{ }^{171} \mathrm{~S}$ residues (Table 1) display typical geometric and coordinated symmetry to bind one $\mathrm{Mg}^{++}$atom (Pihlajamaa et al., 2013).

It has been shown that the VWA domain is involved in PFTRAP dimerisation for attachment to stromal surfaces and fast gliding motility (Pihlajamaa et al., 2013); hybrid cHABP $3277 / 79$ covering the ${ }^{205} \mathrm{C}-\mathrm{C}^{212}$ loop is located in this domain. cHABP $3277{ }^{197} \mathrm{AFNR}^{200}$ establishes H-bonds with CHABP $3279{ }^{201} \mathrm{FLV}^{203}$ sequence to form a niche where an unrecognised receptor binds (Figure 1D). cHABP 3287 , including ${ }^{250}(\mathrm{WSPCSV})^{255}$ motif in the TSR-1 region, and 3289 , completely including ${ }^{254}$ (SVTCGK) ${ }^{259}$ in the TSR-2 region (Song et al., 2012), contain a $\beta$-ribbon region (Table 1 and Figure 1D) connecting vWA and TSR domains to allow TRAP to become elongated and straightened to resist the tensile force exerted by receptor-bound TRAP and the intracytoplasmic actino-myosin motor machinery interaction (Song et al., 2012).

CHABP $3289{ }^{259} \mathrm{~K},{ }^{262} \mathrm{R},{ }^{264} \mathrm{R}$ and ${ }^{265} \mathrm{~K}$ residues and sidechain ${ }^{247} \mathrm{~W}$ and ${ }^{250} \mathrm{~W}$ residues in CHABP 3287 in the 2 antiparallel (A and $B$ ) and ripped $\beta$-sheet form a continuous, positively-charged surface where ligands like heparin and heparin sulphate bind (Figure 1D). X-ray crystallography has shown a fucose residue interacting with ${ }^{261} \mathrm{~T}$ in the $\beta$-turn formed by ${ }^{258}(\mathrm{GKGT}){ }^{261}$ connecting the $A$ and $B$ strands and present in CHABP 3289 (Tucker, 2004), suggesting this carbohydrate is a liver ligand in a still unrecognised receptor for this CHABP.

TRAP cHABP 3347, completely included in the 34 mer-long aldolase binding peptide connecting TRAP with the actinmyosin motor machinery propelling $\mathrm{Spz}$ gliding motility (Buscaglia et al., 2003), is located 20 residues downstream this protein's canonical cleavage site from Spz surface by a rhomboid protease (Ejigiri et al., 2012) recognised as being essential for Spz motility and infectivity. The only TRAP cHABP for which no function has yet been assigned is 3243 which binds with high affinity to hepatocytes and may be involved in host cell entry.

\section{Spz cHABPs as mediators of cell traversal activity}

A sporozoite leaves the skin by gliding in a random, freely cork-screw-like movement to find a small blood vessel to 
A. SPOROZOITE PROTEINS LOCALIZATION \& FUNCTION
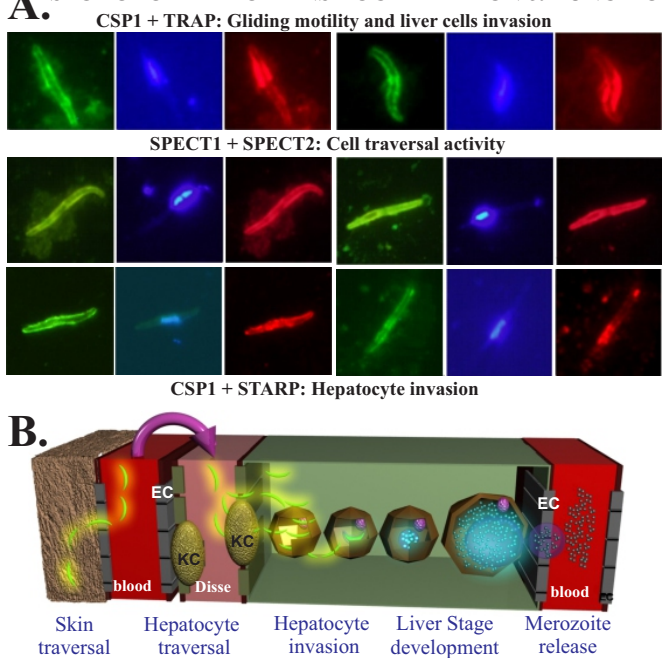

C.
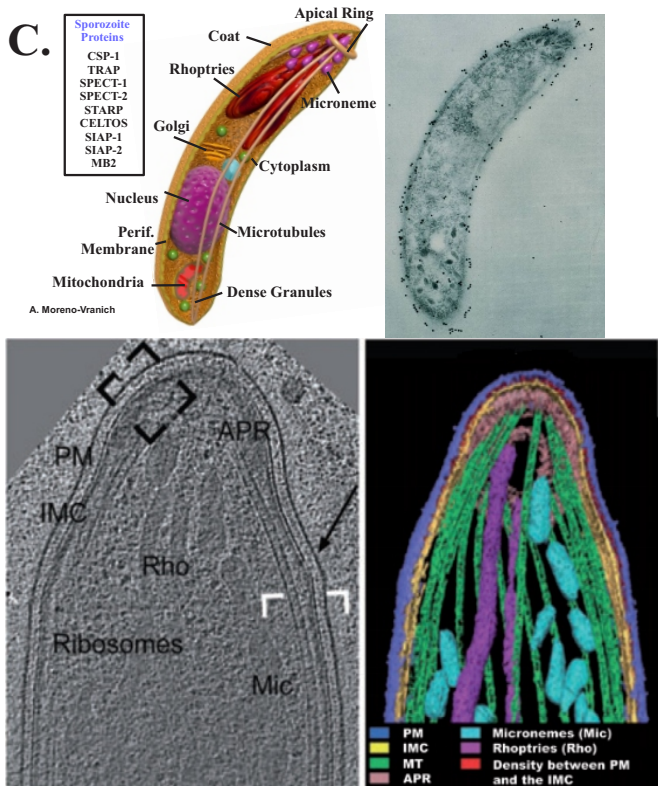

D.

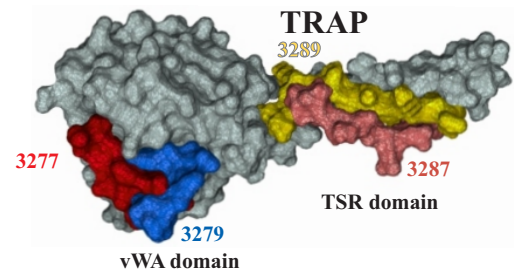

E. MEROZOITE PROTEINS LOCALIZATION \& FUNCTION
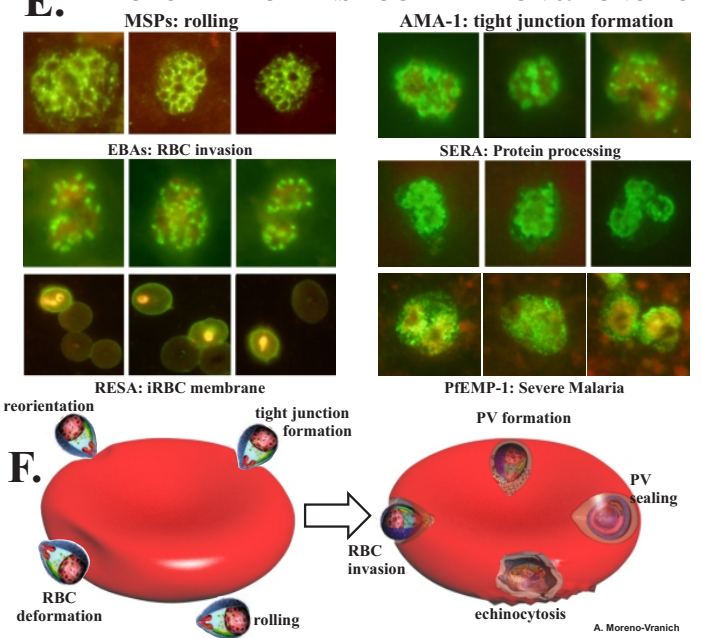

G.
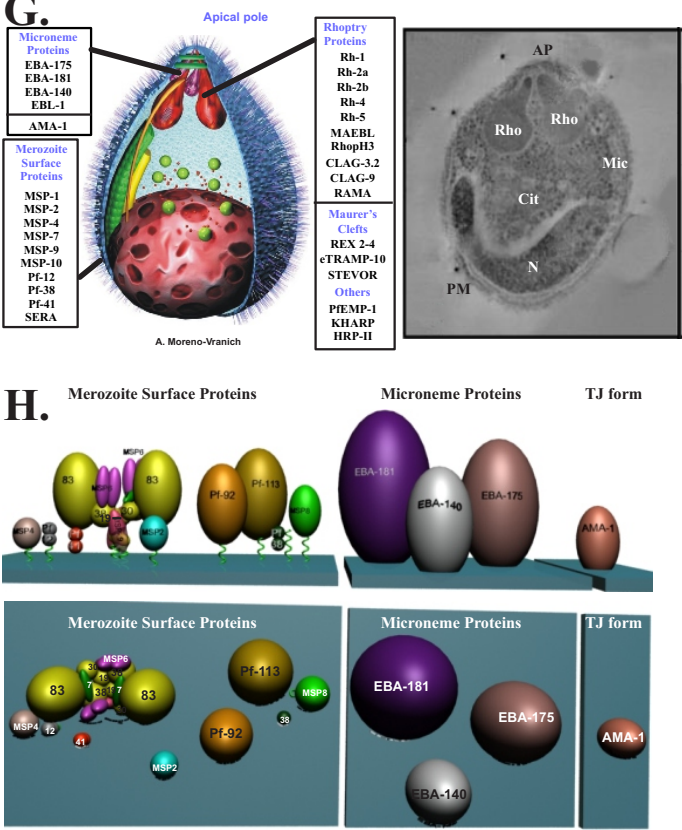

I.

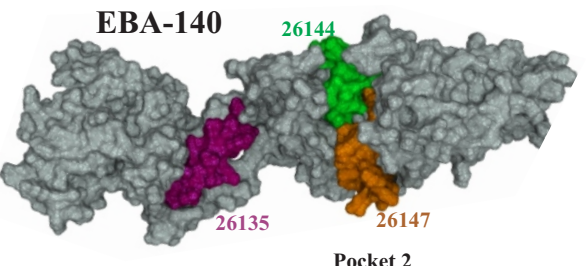

Figure 1. From parasites to atoms

Column 1. Plasmodium falciparum (A) sporozoite protein location is shown, as detected by double immunofluorescence antibody test (IFA) staining with Aotus monkey sera immunised Spz protein-derived mHABPs. The top line shows CSP1 on the membrane (green) and TRAP micronemes (red) involved in gliding motility and cell invasion; the middle line shows SPECT 1 (green) and SPECT 2 (red) involved in cell traversal; the bottom line shows CSP1 on the membrane (green) and intracytoplasmic STARP (red). (B) The sporozoite's journey (fluorescent larvae-like structures: KC (Kupffer cells), EC (endothelial cells) and activities after passing the skin to the liver, adapted from (Vaughan et al., 2008). (C) P. falciparum sporozoite's structural features. Top: Spz anatomy showing its invasion machinery proteins and essential organelles adapted from (Kudryashev et al., 2010) and immune electron microscopy showing anti-CSP antibody reactivity with Spz membrane (black dots on the membrane), adapted from (Kudryashev et al., 2010). Bottom: Electron microscopy of Spz apex positioning and subpellicular network. PM; peripheral membrane, DGP, dense granules; Mic, micronemes; Rho, rhoptry; Mt, microtubules; $\mathrm{Ct}$, cytostome; ApPR, apical, pole ring; N, nucleus; Mit, mitochondria and Ap, apicoplast. Spz apical end, displayed as a projection through a tomogram (left) and volume rendered (right). (D) TRAP 3D structure (PDB: 4F1J) and thrombospondin repeat (TSR) type 1 domain, von Willebrand factor $\mathrm{A}$ and CHABP location. Column 2. P. falciparum (E) merozoite protein location is shown, as determined by IFA and functions: rolling on the membrane by MSPs, TJ formation mediated by AMA-1-and apical rhoptries proteins, RBC deformation and invasion by microneme EBAs, protein processing by intracytoplasmic SERA-5, iRBC membrane expression by RESA and severe malaria (SM) and echinocytosis by PfEMP-1. (F) Steps (clockwise) involved in RBC invasion by merozoites. (G) Protein location in organelles recognised by EM. (H) Representation of Mrz protein location and interactions according to approximate molecular weight (I) EBA-140 3D structure (PDB 4GF2) and cHABP location. 

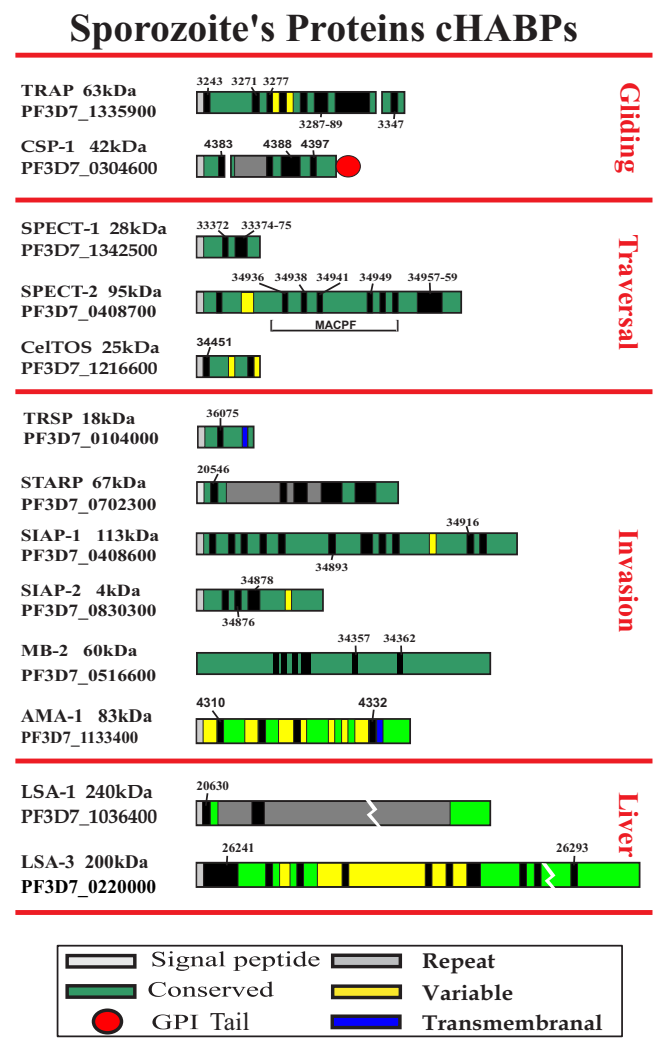

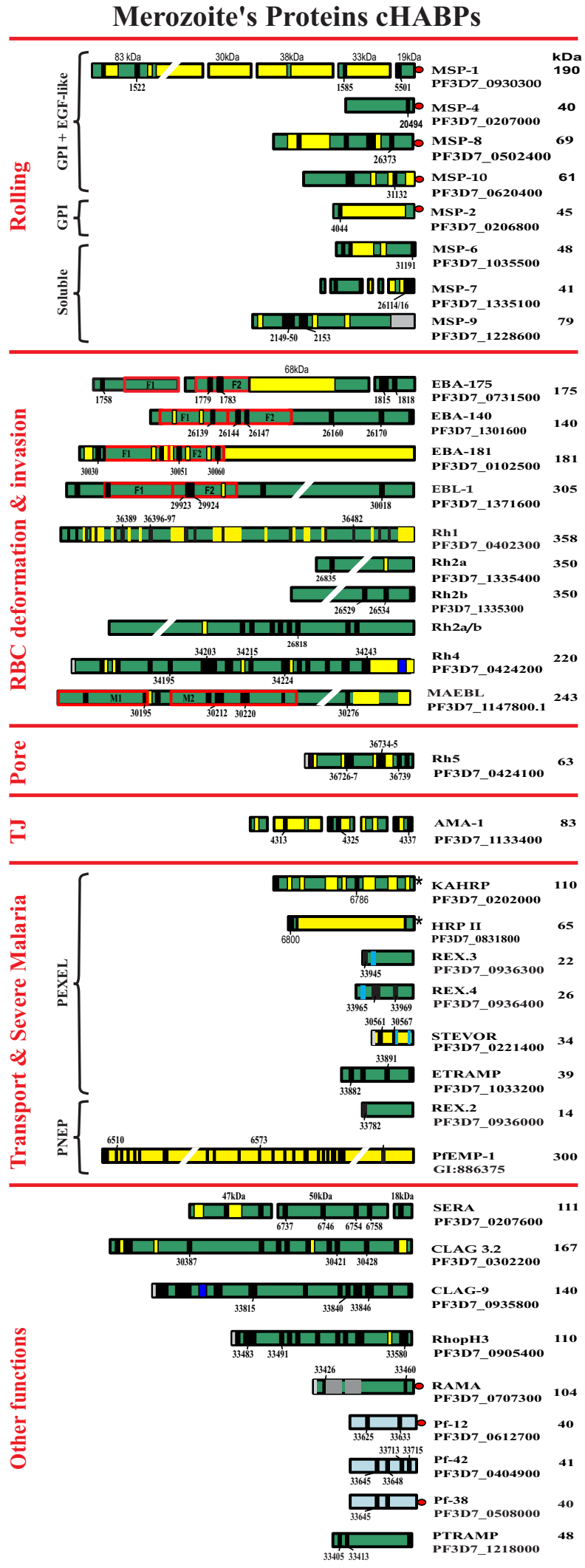

Figure 2. A. Schematic representation of the most important Plasmodium falciparum Spz proteins and the location of their functional cHABPs (black). B. Schematic representation of the most important Plasmodium falciparum Mrz proteins and the location of their functional cHABPs (black). The molecular mass and sequence accession codes are shown for each molecule. The bar length represents approximate molecular weight. The colour code is described in the convention summary at the bottom of this Figure. Abbreviations: GPI, glycosylphosphatidylinositol anchor; EGF, epidermal growth factor-like structures; HMIC, high molecular weight complex; PEXEL, plasmodium export element; Gly, glycophorin A, B or C. 
Table 1. Conserved high activity binding peptides (cHABPs) perform critical biological functions in $P$. falciparum.

The sequence is shown for each CHABP and associated with the relevant functions which they perform in malarial parasite invasion and development. Each critical residue in each CHABP is shown in bold and the physicochemical constants (dissociation constant, Kd and number of receptor sites per cell, NRSC) regarding interactions between cHABPs and host cells are shown in columns. An additional bar has been included to show cHABPs which are common to $\mathrm{Rh} 2 \mathrm{a}$ and $\mathrm{Rh} 2 \mathrm{~b}$ proteins, called $\mathrm{Rh} 2 \mathrm{a} / \mathrm{b}$. ND = not determined, $\mathrm{NS}=$ non-saturated, EGF=epidermal growth factor-like, HMIC=high molecular weight complex, PEXEL=plasmodium export element, Gly=glycophorin A, B or C. PSAC=Plasmodium surface anion channel.

\section{Sporozoite's cHABPs}

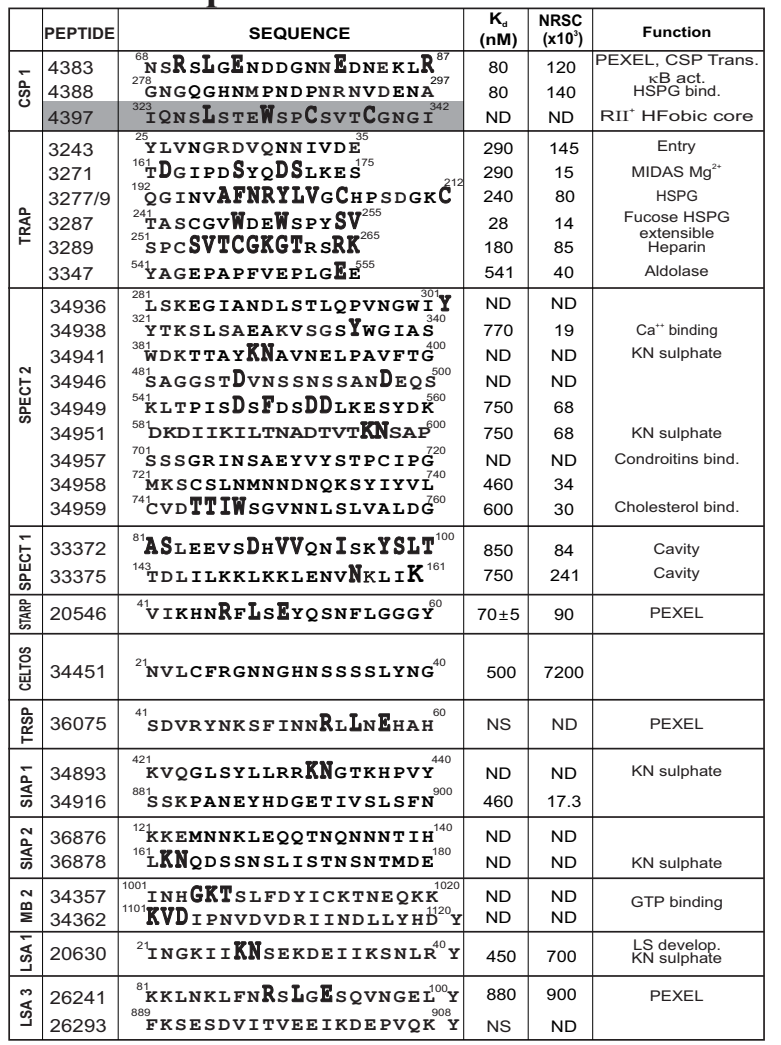

\section{Merozoite's cHABPs I}

\begin{tabular}{|c|c|c|c|c|c|}
\hline & PEPTIDE & SEQUENCE & $\begin{array}{c}\mathrm{K}_{\mathrm{d}} \\
(\mathrm{nM})\end{array}$ & $\begin{array}{l}\text { NRSC } \\
\left(\mathbf{x} 10^{3}\right)\end{array}$ & Function \\
\hline$\frac{0}{2}$ & $\begin{array}{l}1522 \\
1585 \\
5501\end{array}$ & 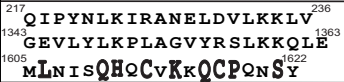 & $\begin{array}{l}150 \\
180 \\
230\end{array}$ & \begin{tabular}{l|}
6.3 \\
10.6 \\
11.8
\end{tabular} & $\begin{array}{c}\text { Gly A } \\
\text { Heparin } \\
\text { K5-NSOS-H } \\
\text { EGF }\end{array}$ \\
\hline $\mid$ & 20494 & ${ }^{221}$ EYVGNRRVKCKCKEGYKLEG ${ }^{240}$ & 470 & 24 & EGF \\
\hline 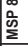 & 26373 & ${ }^{498}$ C PLNSNCYVIDDEETCRCL $P^{517}$ & 450 & 200 & EGF \\
\hline 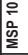 & 31132 & ${ }^{422}$ KCGPN SRCY IVEKDKEQCRC ${ }^{441}$ & 600 & 17.6 & EGF \\
\hline $\begin{array}{l}0 \\
\vdots \\
\vdots \\
\vdots\end{array}$ & 31191 & ${ }^{352}$ E I D S T I NN LVQEM I H L F SNN ${ }^{371}$ & 150 & 128 & $\begin{array}{l}\text { HMIC } \\
\text { Tetramer }\end{array}$ \\
\hline 金 & $\begin{array}{l}26114 \\
26116\end{array}$ & $\begin{array}{l}{ }^{301} \mathrm{KDKEYHEQFKNYIYGVYSY}^{320} \\
{ }^{332} \mathrm{~K} \text { KEEEYKKLEYSFNLLNTM } \\
{ }^{351}\end{array}$ & $\begin{array}{l}\text { NS } \\
450\end{array}$ & $\begin{array}{l}\mathrm{ND} \\
85.3\end{array}$ & HMIC \\
\hline $\mid \begin{array}{l}0 \\
\frac{i}{2} \\
\frac{m}{2}\end{array}$ & $\begin{array}{l}2149 \\
2150 \\
2153\end{array}$ & 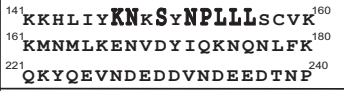 & $\begin{array}{r}73 \\
80 \\
\text { ND }\end{array}$ & $\begin{array}{l}9.0 \\
7.6 \\
\text { ND }\end{array}$ & $\begin{array}{l}\text { Hemolysin } \\
\text { HMIC }\end{array}$ \\
\hline 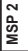 & 4044 & ${ }^{2}$ KNESKYSNTF INNA ${ }_{\text {NMS S IR }}{ }^{21}$ & 140 & 12 & Lipids bind. \\
\hline 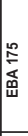 & \begin{tabular}{|l|}
1758 \\
1779 \\
1783 \\
1815 \\
1818 \\
\end{tabular} & 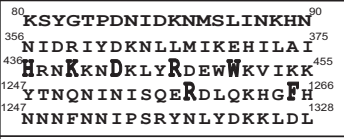 & $\begin{array}{l}112 \\
175 \\
139 \\
106 \\
146\end{array}$ & \begin{tabular}{l|}
15 \\
14.6 \\
7.5 \\
8.0 \\
9.4
\end{tabular} & $\begin{array}{l}\text { R II-F1 } \\
\text { Glycan5, dimer. } \\
\text { R II-F2 } \\
\text { RV micron. traf. } \\
\text { RVI micron. traf. }\end{array}$ \\
\hline 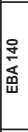 & \begin{tabular}{|l|}
26139 \\
26144 \\
26147 \\
26160 \\
26170 \\
\end{tabular} & 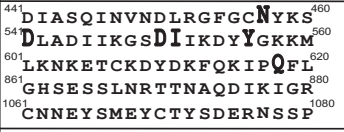 & $\begin{array}{l}350 \\
500 \\
590 \\
600\end{array}$ & $\begin{array}{l}3.8 \\
6.8 \\
1.1 \\
3.1\end{array}$ & $\begin{array}{l}\text { Acetamide } \\
\text { GlyC in F2 }\end{array}$ \\
\hline 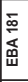 & \begin{tabular}{|l|}
30030 \\
30051 \\
30060 \\
\end{tabular} & 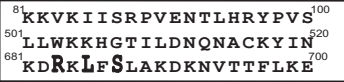 & $\begin{array}{l}394 \\
595 \\
178\end{array}$ & $\begin{array}{l}2.1 \\
1.5 \\
0.6\end{array}$ & PEXEL \\
\hline$\overline{\vec{m}}$ & $\begin{array}{l}29923 \\
29924 \\
30018\end{array}$ & 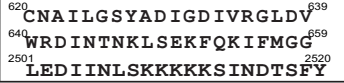 & $\begin{array}{l}415 \\
450 \\
245\end{array}$ & $\begin{array}{c}10.5 \\
7 \\
8\end{array}$ & $\begin{array}{l}\text { Gly B } \\
\text { Gly B }\end{array}$ \\
\hline
\end{tabular}

\section{Merozoite's cHABPs II}

\begin{tabular}{|c|c|c|c|c|c|}
\hline & PEPTIDE & SEQUENCE & $\begin{array}{c}\mathrm{K}_{\mathrm{d}} \\
(\mathrm{nM})\end{array}$ & $\begin{array}{l}\text { NRSC } \\
\left(\times 10^{3}\right)\end{array}$ & Function \\
\hline \multirow{4}{*}{$\frac{\bar{\Sigma}}{\alpha}$} & 36389 & ${ }^{601}$ IYIQPILNNLHTLKQVQNNK ${ }^{620}$ & ND & ND & \multirow{4}{*}{ Ca" signal } \\
\hline & 36396 & ${ }^{74} \mathrm{KY}$ I LKQKD IEL TQHVY TDEK ${ }^{760}$ & ND & ND & \\
\hline & 36397 & ${ }^{76}$ INDYLEE IKNEQNK IDKTID ${ }^{780}$ & ND & ND & \\
\hline & 36482 & ${ }^{2462} I_{K}$ E Q KN I Y TQKE I D I SK I I K ${ }^{2481}$ & ND & ND & \\
\hline 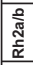 & 26818 & 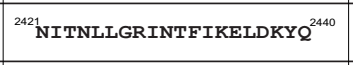 & 300 & 97 & \\
\hline 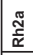 & 26835 & ${ }_{\text {LEREK }}^{2761}$ E Q L QKEEELKRQE $Q^{2780}$ & 250 & 5.3 & \\
\hline \multirow[b]{2}{*}{$\begin{array}{l}\stackrel{N}{\frac{N}{\alpha}} \\
\frac{\pi}{\alpha}\end{array}$} & 26529 & ${ }^{3021}$ SD I HMD SVD I HD S ID TDENA ${ }^{3040}$ & 200 & 10 & \multirow[b]{2}{*}{ PEXEL } \\
\hline & 26534 & ${ }^{3121}$ TTEKLVDIYPSTYRTLDEPM ${ }^{3140}$ & 300 & 40 & \\
\hline \multirow{5}{*}{$\frac{t}{\alpha}$} & 34195 & ${ }^{461}$ CTNIKKYTDDICLSIKPKAL ${ }^{480}$ & 870 & 180 & \multirow{5}{*}{$\begin{array}{l}\text { CR1 binding } \\
\text { CR1 binding } \\
\text { Trypsin, chymotrypsin } \\
\text { ultra-sens. } \\
\text { Trypsin, chymotrypsin } \\
\text { ultra-sens. } \\
\text { Trypsin, chymotrypsin } \\
\text { ultra-sens. }\end{array}$} \\
\hline & 34203 & ${ }_{Q}^{621}$ IYKNELKDRIKETQTKINL & 590 & 90 & \\
\hline & 34215 & ${ }^{86}$ FDY THLWDNA QFTRTKEN I ${ }^{880}$ & 1200 & 150 & \\
\hline & 34224 & ${ }^{1041}$ Y DKLNEHV INNLY TKSKD S L ${ }^{1060}$ & 480 & 60 & \\
\hline & 34243 & ${ }^{1421}$ LNT ILHRNEQTKNATRSYNM ${ }^{1440}$ & 850 & 90 & \\
\hline \multirow{3}{*}{$\frac{n}{\alpha}$} & 36727 & ${ }^{20} \mathrm{GKY} \mathrm{I}_{\mathrm{AVD}} \mathrm{DAF}$ IKK INETY DKV ${ }^{220}$ & 1300 & 65 & Aotus RBC \\
\hline & 36735 & ${ }_{D}^{361}$ EYIHKLILSVKSKNLNKDL ${ }^{380}$ & ND & ND & Basigin \\
\hline & 36739 & ${ }^{44} \mathrm{~K}^{\prime} \mathrm{KLN} I$ WRTF $Q K D E L L K R I L^{460}$ & ND & ND & Basigin \\
\hline \multirow{9}{*}{ 㟧 } & 30195 & ${ }^{401}$ TGSCYFLKKKPTCVLKKENH ${ }^{420}$ & 220 & 16.4 & \multirow[b]{4}{*}{ Salivary Spz } \\
\hline & 30212 & ${ }^{74} \mathrm{~K}$ SK IF SNRFTMKEYDPKTRL ${ }^{760}$ & 300 & 18 & \\
\hline & 30220 & ${ }^{90}$ K SKVFGTFDQKTGKCKS LMD $^{920}$ & 380 & 8 & \\
\hline & 30276 & ${ }^{2021}$ EMD L N Y D K I Y T L AM I NNEE T ${ }^{2040}$ & ND & ND & \\
\hline & 4310 & ${ }^{74} \mathrm{QHAYPIDHEGAEPAPQEQN \textrm {L } ^ { 9 3 }}$ & 670 & 270 & \multirow{5}{*}{$\begin{array}{r}\text { ROM } 1 \text { site } \\
(\odot+\text { +Aldolase }\end{array}$} \\
\hline & 4313 & ${ }_{374}^{134} \tilde{D A E V A G T Q Y R L P S G K C P V F G}^{153}$ & 120 & 11 & \\
\hline & 4325 & ${ }_{514}^{374}$ IK SA F L P T GAFKA D R YK S H ${ }_{533}^{393}$ & 100 & 5.1 & \\
\hline & 4332 & ${ }_{603}^{514}$ AEVTSNNEVVVKEEYKDEYA & 890 & 665 & \\
\hline & 4337 & ${ }^{603}$ WGEEKRASHTTPVLMEKPYY ${ }^{622}$ & ND & ND & \\
\hline \multirow{2}{*}{ 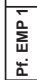 } & 6510 & ${ }^{128}{ }_{\text {GACA PYRRL HVCDQNLEQ IE }}{ }^{147}$ & 119 & 37 & \multirow{2}{*}{$\begin{array}{c}\text { A blood group } \\
\text { Motif }\end{array}$} \\
\hline & 6573 & ${ }^{1257}$ TD I S HDGACMP PRRQKL CL ${ }^{1275}$ & ND & ND & \\
\hline 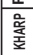 & 6786 & ${ }^{378}$ KSKKHKDHDGEKKKSKKHKD ${ }^{397}$ & 190 & 1 & PEXEL \\
\hline \begin{tabular}{|l}
$\overline{\overline{0}}$ \\
全 \\
\end{tabular} & 6800 & ${ }^{24}$ NN SAFNNNLC SKNAKG LNLN ${ }^{43}$ & 200 & 6 & 2XPEXEL \\
\hline \begin{tabular}{|l|l}
\multirow{2}{*}{} \\
\end{tabular} & 33782 & ${ }^{21}$ DTLGSSNFSPLKPCEGLECL ${ }^{40}$ & NS & ND & PNEP \\
\hline \multirow[b]{2}{*}{ 笞 } & 33945 & MQTRKYNKMLSKVETKQFIY ${ }^{20}$ & 440 & 84.3 & \multirow[b]{2}{*}{ PEXEL } \\
\hline & 33947 & ${ }^{41}$ EGSSFR_LsEPVVEEQDLKK ${ }^{60}$ & ND & ND & \\
\hline \begin{tabular}{|l|l|l}
$\underset{x}{x}$ \\
\end{tabular} & 33965 & ${ }^{61}$ REIN INKN I PSYPVKF SKLE ${ }^{80}$ & 500 & 48.2 & 10X PEXEL \\
\hline \multirow{2}{*}{ 总 } & 30561 & ${ }^{41}$ MKSRRLAEIQLPKC PHYNND ${ }^{60}$ & 110 & 7.7 & \multirow{2}{*}{$\begin{array}{c}\text { PEXEL } \\
\text { Gly C }\end{array}$} \\
\hline & 30567 & ${ }^{161}$ A SCCKVHDNYLDNLKKGCFG ${ }^{180}$ & 90 & 4.0 & \\
\hline 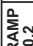 & 33882 & ${ }^{41} E Q D L Q Q K K N R K R N L I L Y S L G G^{60}$ & 900 & 466 & PNEP \\
\hline 起 & 33891 & ${ }^{221}$ TPTESSHGISDGKKDTSTND ${ }^{240}$ & NS & ND & \\
\hline & 6737 & ${ }^{409}$ Y DNILVKMFKTNENNDKSEL $I^{42}$ & 500 & 120 & \\
\hline$\overleftarrow{\S}$ & 6746 & DQGNCDT SWIFASKYHLET I & 150 & 30 & Enzyme \\
\hline 岃 & 6754 & ${ }^{749}$ Y KKVQNLCGDDTADHAVNIVG & 1100 & 100 & Enzyme \\
\hline & 6758 & ${ }^{829}$ KTTKKESKIYDYYLKASPEF $^{48}$ & ND & ND & Enzyme block \\
\hline लू & 30387 & ${ }^{340}$ VYY SEKKRRKTYLKVDRS S T ${ }^{359}$ & 107 & 2.2 & \\
\hline $\begin{array}{ll}4 \\
0\end{array}$ & 30421 & ${ }^{1020}$ S S L PPYAKKP I TQLKYGK T ${ }^{1039}$ & 255 & 1.8 & PSAC \\
\hline u & 30428 & ${ }^{1160} \mathrm{~L} D A Y K S F P G G F G P A I K E Q T Q^{179}$ & 416 & 3.4 & \\
\hline & 33815 & 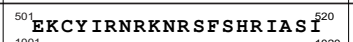 & 600 & 1.400 & \\
\hline 要 & 33840 & ${ }_{\text {MYDKLTNVFF PMNIKKPTI }}^{1020}$ & 300 & 480 & \\
\hline वे & 33846 & ${ }^{1121}$ G GNMLYRNILYF PNHLPEE L ${ }^{1140}$ & NS & ND & \\
\hline$\stackrel{m}{x}$ & 33483 & ${ }^{81}$ KFRVPKHLKDKNIHNFTPTL ${ }^{100}$ & 465 & 168 & HMIC \\
\hline T⿳亠口冋口ㅇ & 33491 & ${ }^{623}$ PKEFELIKSRMIHPN IVDRI I ${ }^{642}$ & 540 & 176 & \\
\hline$\frac{c^{\circ}}{\alpha}$ & 33570 & ${ }^{643}$ LKG I DN LMK S TRY DKMR TMY ${ }^{662}$ & 680 & 38 & \\
\hline 表 & 33426 & ${ }^{79}$ NINILSSVHRKGRIIYDSF ${ }^{97}$ & 400 & 180 & PEXEL \\
\hline 在 & 33460 & ${ }^{765}$ HKKREKS ISPHSYQKVSTKV ${ }^{785}$ & 400 & 34 & H-ATPase \\
\hline$\dddot{\dddot{t}}$ & 33631 & ${ }^{221}$ I G F KCPSNY SVEPHDCFVS $\mathrm{A}^{240}$ & ND & ND & \\
\hline & & & & & \\
\hline 蛋 & 33645 & ${ }^{141}$ VLR IH I SNGVLRK I PGCDFNY & 550 & 24,6 & \\
\hline & 33713 & 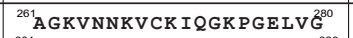 & 350 & 24 & \\
\hline$\frac{t^{2}}{a}$ & 33715 & ${ }^{301}$ LHKNKVTDLKTL I PGYASYT & 550 & 40.2 & \\
\hline 产 & 33405 & ${ }^{21}$ YISSNDLTSTNLKVRNNWE ${ }_{195}^{40}$ & 170 & 17 & \\
\hline 営 & 33413 & ${ }^{177}$ LEGP IQF SLGKS SGAFR IN ${ }^{195}$ & 200 & 17 & \\
\hline
\end{tabular}


traverse endothelial cells twice, entering it to navigate in the blood stream and leaving it when arriving at the liver (Amino et al., 2008). It stops in the Disse space and the liver sinusoidal cell layer to start searching for a hepatocyte to infect (Figure 1B). The liver sinusoids are a unique vascular system having a fenestrated endothelium where an extracellular highly-rich heparin sulphate proteoglycan (HSPG) matrix protrudes, separating endothelial cells from hepatocytes where Kupffer (phagocytic) cells are also present to destroy all potentially dangerous particles (Figure 1B).

Cell trespassing (or cell traversal activity) (Mota et al., 2002) is mediated by a set of proteins, the most relevant being sporozoite protein essential for cell traversal 1 and 2 (SPECT 1 and 2) (Ishino et al., 2004) and cell traversal protein for ookinetes and sporozoites (CelTOS) (Kariu et al., 2006) and thrombospondin related sporozoite protein (TRSP) (Labaied et al., 2007) (Figures 1C and 2A).

SPECT-2 (Plasmodium perforin-like protein 1 (PPL-1)), a $\mathrm{Spz}$ micronemal $95 \mathrm{kDa}$ protein translocated to $\mathrm{Spz}$ membrane during infection (Kaiser et al., 2004) (Figure $1 \mathrm{~A})$, contains a membrane attack complex/perforin-related (MACPF) domain. When SPECT 1 and 2 are genetically knocked out (KO), such Spz can glide but cannot traverse through host cells in vivo or in vitro (Ishino et al., 2004).

The SPECT-2/MACPF domain is highly homologous to complement system proteins $\mathrm{C} 6$ to $\mathrm{C} 9$, especially $\mathrm{C} 8 \alpha$, having a similar function regarding pore formation and permeabilisation of host cell membranes, very similar to many microbial pore-forming toxins (PFT) and cholesteroldependent cytolysins (CDC) secreted by Gram-positive bacteria (Rosado et al., 2008).

The C8 $\alpha$ MACPF domain (recombinant fragment 103-462 residues) 3D structure determined by X-ray crystallography shows centrally-kinked, $\sim 90^{\circ}$ four-stranded, $\beta$-sheets surrounded by $\alpha$-helices and $\beta$-strands forming the D1 and D3 structural segments, similar to the intermedilysin (ILY) CDC proteins which also contain D2 and D4 segments. D4 mediates membrane binding in CDCs and D2 links D1 and D3 for pore formation (Hadders et al., 2007); (Giddings et al., 2004).

cHABP 34936 contains ${ }^{301} Y$ which creates a hydrophobic niche in this MACPF structure, establishing an $\mathrm{H}$-bond and $\pi$ resonant structure with cHABP $34938{ }^{335} Y$ where host cell membrane phosphocholine (PC) binds to mediate cell traversal activity (De Colibus et al., 2012). SPECT 2 cHABP 34941 contains the $\mathrm{KN}$ sequence also present in cHABP 34951 suggested as the binding motif for heparinsulphate (HS) moieties (Polekhina et al., 2005).

MACPF C2 region 34949 peptide contains the ${ }^{547} \mathrm{DX}{ }^{549} \mathrm{FXX} \mathrm{X}^{552} \mathrm{D}^{553} \mathrm{D}$ motif which, together with ${ }^{487} \mathrm{D}$ in cHABP 34946, has the coordinated sequence and orientation for $\mathrm{Ca}^{++}$binding (in the calcium binding region 1 or CBR1) after which a strong interaction with host membrane begins (Law et al., 2010).
Outside the MACPF domain, cHABP 34957 binds chondroitin sulphate (CS) in a niche created with 34958 . cHABP 34959 contains the ${ }^{744} \mathrm{TT} / \mathrm{I} / \mathrm{W}^{747}$ motif which specifically binds cholesterol in ILY (CDC) microbial perforins.

Recent interest has been shown in SPECT-1; its 3D structure has shown (Hamaoka and Ghosh, 2014) that host cell cholesterol and/or heparin-like and/or dematan-like oligosaccharides having high or low sulfate content can fit in the $\sim 750 \AA^{3}$ cavity entirely containing cHABP $33372\left({ }^{81} \mathrm{~A}\right.$ to ${ }^{97} \mathrm{Y}$ ) and ${ }^{156} \mathrm{~N}$ and ${ }^{161} \mathrm{~K}$ in $\mathrm{CHABP} 33375$. SPECT 1 cHABP 33372 also contains ${ }^{98} \mathrm{~S},{ }^{99} \mathrm{~F} / \mathrm{L}$ and ${ }^{100} \mathrm{~T} / \mathrm{S}$ forming a juxtaposing deep pocket where a still unrecognised receptor binds (Hamaoka and Ghosh, 2014).

CelTOS, a Spz protein, is present in different host-invasive stages, playing a critical role in breaking through cell barriers. Targeted disruption of the CelTOS gene reduces parasite infectivity 200 -fold in the mosquito host and Spz infectivity in the liver, abolishing Spz cell-passage ability (Kariu et al., 2006). Two HABPs have been identified: highly conserved 34451 and highly variable, antigenic and immunogenic HABP 34458 (therefore not included in this manuscript) (Curtidor et al., 2012).

MB2 is a $185 \mathrm{kDa}$ protein expressed in Spz, liver stage (LS), blood-stage (BS) parasites and gametocytes. This protein has an amino-terminal basic, a central acidic and a carboxyl-terminal domain, the latter having great similarity with the GTP-binding domain where peptide 34357 containing $X^{1004} \mathrm{GTK}^{1006}$ and 34362 containing ${ }^{1101} \mathrm{KDV}^{1103}$ coordinate and bind GTP from prokaryotic translation initiation factor 2 (Nguyen et al., 2001) (ArévaloPinzón and Curtidor, unpublished results).

Sporozoite invasion-associated protein-1 and -2 (SIAP-1/ S5 and SIAP-2) (113kDa and $45 \mathrm{kDa}$ respectively) have similar location on Spz membrane to that of CSP-1 and participate in cell traversal and hepatocyte invasion. Differential proteomic analysis has shown that these proteins' expression is increased $10 \mathrm{X}$ and $4.4 \mathrm{X}$, respectively, when $\mathrm{Spz}$ incubation temperature rises from $24^{\circ} \mathrm{C}$ to $37^{\circ} \mathrm{C}$, similar to what occurs when Spz are transmitted from a mosquito's salivary glands to human skin during the mosquito bite (Siau et al., 2008).

SIAP-1 cHABPs 34893 and 34916 bind specifically to HeLa and hepatocyte cells, the former containing $\mathrm{KN}$ sulphatebinding motifs while SIAP-2 cHABPs 36876 and 36878 only bind HepG2 cells (Arevalo-Pinzon et al., 2011); the latter also has the $\mathrm{KN}$ binding motif. Antibodies against SIAP-2 have significantly decreased cell traversal percentage in dose-dependent inhibition of invasion (Siau et al., 2008). Anopheles mosquitoes infected with siap-1(-) parasites cannot transmit malaria to susceptible rodents, despite the normal formation of $\mathrm{Spz}$ in their midgut (Engelmann et al., 2009).

\section{Multi-functional CSP-1}

Last but not least, due to its tremendous impact in the malaria vaccine development process the CSP-1 
multifunctional protein which accounts for $5-15 \%$ of total $\mathrm{Spz}$ [ ${ }^{35} \mathrm{~S}$ ] methionine incorporation, densely coating Spz surface (Figure 1C) displays a common characteristic molecular structure in all Plasmodium parasites, having a variable length and composition central tandem repeat region (CRR) consisting of a highly antigenic and immunogenic major tetrapeptide (NANP) repeated 30-40 times intercalated 4 times with a minor repeat (NVDP) sequence (Dame et al., 1984). CRR (originally suggested as the most relevant epitope for antimalarial vaccine development, though discarded after numerous human trials) has recently been found to be critical for Spz formation and maturation during sporogony in oocyst development inside the mosquito's midgut (Ferguson et al., 2014).

The CRR is flanked by two relatively conserved regions (RI and RII) (Dame et al., 1984). RI has two RxLxE Plasmodium export element (PEXEL) motifs, one completely included in the N-terminus of cHABP 4383 involved in CSP entry to hepatocyte cytoplasm to promote parasite development in the liver (Singh et al., 2007). 4383 also contains the target amino acid sequence for protective antibody induction in its C-terminal portion $\left({ }^{81} \mathrm{E}\right.$ to $\left.{ }^{87} \mathrm{R}\right)$ (Espinosa et al., 2015). cHABP 4383 is located 5 residues upstream the ${ }^{101}(\mathrm{KKLKQP})^{106}$ motif used by CSP-1 to bind to glucosamine glycan (GAG) and heparan sulphate (HS) moieties present on hepatocyte membrane (Rathore et al., 2002). This KKLKQP sequence also becomes the CSP-1 cleavage site once $\mathrm{Spz}$ contacts the highly sulphated proteoglycans on hepatocyte membrane (but not dermal cells), releasing a $\sim 10 \mathrm{kDa} \mathrm{N}$-terminal fragment covering, protecting and masking mature CSP-1 protein and its adhesive cell domain in mosquito salivary gland $\mathrm{Spz}$ to be exposed to the hepatocyte cell adhesive domain in a vertebrate host (Coppi et al., 2011). KKLLKQ has very recently been suggested as an equally efficient noncanonical PEXEL motif (Schulze et al., 2015).

cHABP 4388, completely containing an amino acid sequence linking CRR to RII, is located 15 residues upstream the high content HSPG binding region on hepatocyte membrane to which Spz bind and halt their motion to start invasion and reproduction inside liver cells (Frevert et al., 1993).

$3 \mathrm{D}$ structure has shown that $\mathrm{RII}$ in the $\mathrm{II}^{+}$region completely contains cHABP 4397, immediately followed by VRVRKRKNV (nuclear localisation signal, NLS), to enter the hepatocyte nucleus (Singh et al., 2007). cHABP 4397 is topologically located in strand 1 where ${ }^{331} \mathrm{~W}$ interacts with neighbouring non-binding ${ }^{345} \mathrm{R}$, generating a $\pi$-cation interaction where hepatocyte HSPG can bind in a hydrophobic groove where ${ }^{327} \mathrm{~L}$ forms part of the wall. This region structurally and functionally resembles TRAP TSR region, having two antiparallel $\beta$-strands and defined $\beta$ turns stabilised by ${ }^{334} \mathrm{C}$ and ${ }^{338} \mathrm{C}$, rather than the ripped $\beta$ strand in TRAP having an $\alpha 1$ helix in CSP-1 (Tossavainen et al., 2006).

TRSP is a $18 \mathrm{kDa}$ (163 aa long) protein located in Spz rhoptries, containing a characteristic signal sequence (SS) and a C-terminal hydrophobic region and a TSR domain in its $\mathrm{N}$-terminal region, playing a relevant role in hepatocyte entry (Kaiser et al., 2004). cHABP 36075 is located 3 residues upstream this protein's $\mathrm{RII}^{+}$region and has a PEXEL motif (Curtidor et al., 2012).

Disappointing results have been obtained in countless human trials using large recombinant, DNA or vector-based vaccines including $P$. falciparum $\mathrm{Spz}$ proteins such as CSP-1. This would suggest the need to include some others functionally-relevant epitopes in such vaccine, like cHABPs candidates derived from CSP-1, TRAP, SPECT 1, 2, CelTOS, MB2, TRSP, SIAP-1 and 2 to be used as components of a minimal subunit-based, multi-epitope, multistage, chemically-synthesised antimalarial vaccine (Curtidor et al., 2011; Garcia et al., 2006; Patarroyo et al., 2011).

\section{Liver stage cHABPs}

Spz dramatically change their morphology after invading hepatic cells (Hegge et al., 2010; Kappe et al., 2003); the liver stage (LS) reproduction cycle begins, implicating several molecules. The most studied from the immunological point of view have been liver stage antigens 1 and 3 (LSA 1, 3), STARP and SPATR (Daubersies et al., 2000; Fidock et al., 1994b; Fidock et al., 1997; Kurtis et al., 1999). Interestingly, all these LS proteins have degenerated highly antigenic and immunogenic tandem repeat regions, varying in length and copy number, mostly deposited as flocculent material inside infected hepatocytes and considered decoy fragments to distract the immune response (Fidock et al., 1994b; Fidock et al., 1997).

Only cHABP 20630 has been found in the $240 \mathrm{kDa}$ LSA-1 protein in non-repeat region $A$ (NR-A); it has high binding affinity to both hepatocytes and RBC and has the sulphate binding $\mathrm{KN}$ motif, lacking any other known biological function (Curtidor et al., 2011).

The very relevant, highly immunogenic $200 \mathrm{kDa}$ LSA-3, now in human trials, expressed on Spz and the periphery of maturing hepatic Mrz, has one NR-A, followed by repeat I region, along with $\mathrm{R} 2$, an NR-B, short R3 and a Cterminal NR-C (Daubersies et al., 2000). cHABP 26241 has a PEXEL motif in the NR-A, suggesting that this protein could be transported thorough the membranes to infected liver cell surface, whilst cHABP 26293 in NR-B has been assigned no recognised biological function to date (Curtidor et al., 2011).

Little is known about the biological function of $78 \mathrm{kDa}$ sporozoite threonine/asparagine rich protein (STARP) but the fact that it is a Spz membrane protein (identified by electron microscopy and immunofluorescence in the early ring stages of erythrocyte development (Fidock et al., 1994a)) confers appropriate support for its inclusion as a vaccine component. This is further supported by the fact that cHABP 20546 has a PEXEL motif, suggesting that it is transported to hepatocyte and RBC membranes and largescale serological analysis in African hyper-endemic areas has placed STARP as the second most relevant molecule 
in sterile protective immunity induction prior to the high malaria transmission season (Fidock et al., 1997).

Most Spz proteins and their corresponding cHABPs which are relevant in the cell host-microbial interactions described here have been recognised by total and putative proteomics of $P$. falciparum salivary gland Spz (Lindner et al., 2013).

\section{The asexual blood stage \\ New strategies for new targets: RBC}

$\mathrm{Spz}$ have incredibly fast proliferation and differentiation speed where infected hepatocytes produce 30,000 new descendants in one week which can change their morphology into round, pear-shaped structures, named Mrz, having completely different biochemical and functional characteristics to enable them to invade their new target: the RBC (Figure 1E, G). The very elegant work by Alan Cowman (Weiss et al., 2015) and some other groups during the last few years has shown the coordinated sequence of events in Mrz invasion of RBC through live cell imaging filming and super resolution (Riglar et al., 2011).

\section{Mrz cHABPs involved in initial contact with RBC}

Initial contact involves weak receptor-ligand interaction during Mrz rolling on RBC surface, inducing slight erythrocyte deformation mediated by heparin-like receptors (Boyle et al., 2010) and MSP proteins like MSP1, -2, -4, -8, -10 anchored to the RBC membrane via a glycosylphosphate-inositol (GPI) tail (Figure 1F) (Sanders et al., 2005; Sanders et al., 2006) which are non-covalently associated with other peripheral membrane proteins like MSP-6, -7 and 9, forming high molecular invasion complexes (HMIC) (Figure 1H) (Boyle et al., 2010).

The above is followed by dramatic RBC deformation, depending on actin-myosin motor activation mediated by strong receptor-ligand interactions, involving microneme stored and surface transport erythrocyte binding antigens (EBA 175, 140, 181, and EBL) and rhoptry stored and surface discharged reticulocyte binding-like proteins (Rh1, Rh2a, 2b, Rh4) (Figure 1G). Pore formation then involves Rh5-basigin interaction, followed by tight junction (TJ) formation mediated by the AMA1-RON2 complex which facilitates invasion of RBC. Transient echinocytosis formation of infected red blood cells (iRBC) lasts 5-10 minutes, probably caused by RBC dehydration and recovery to their normal shape when Mrz become rings to start the reproduction cycle (Paul et al., 2015; Weiss et al., 2015). All these proteins' cHABP fundamental functions are analysed below (Figure 1F).

MSP-1 is the most abundant $200 \mathrm{kDa}$ protein expressed on Mrz surface (Gilson et al., 2006). It forms an HMIC with the MSP6 and MSP7 in the endoplasmic reticulum (Figure $1 \mathrm{H}$ ), mediating weak receptor-ligand interactions during parasite rolling (Kauth et al., 2006). MSP1 undergoes primary proteolytic cleavage on the Mrz surface giving rise to $\mathrm{N}$ terminal $83 \mathrm{kDa}$, internal $30 \mathrm{kDa}$ and $38 \mathrm{kDa}$ and $\mathrm{C}$ terminal $42 \mathrm{kDa}$ fragments, followed by a second (calcium enzymatic dependent) cleavage of $\mathrm{MSP}_{42}$ fragment into
$\mathrm{MSP}_{13}$ and MSP1 $1_{19}$ segments (Blackman and Holder, 1992). The second cleavage releases the HMIC to the milieu (Figure 2B), with only the C-terminal GPI-anchored MSP1 19 fragment remaining anchored to the parasite membrane to enter RBC. MSP1 19 has two EGF-like domains shown to be involved in parasitophorous vacuole (PV) development and sealing, where it remains until the end of the intracellular cycle (Dluzewski et al., 2008).

Note: All cHABPs amino acid sequences are shown in Table 1.

Analysis of the MSP1 amino acid sequence and critical binding residues has revealed that all our cHABPs have been deeply involved in these very relevant biological functions (Urquiza et al., 1996). cHABP 1522 is present in the MSP1 ${ }_{83}$ fragment which interacts with the glycophorin $A$ protein fragment (residues 31 to 72 ) (Baldwin et al., 2014); cHABP 1585, located five residues downstream the primary cleavage of MSP1 (generating the MSP142 fragment), interacts with $\mathrm{K} 5-\mathrm{NSOS}-\mathrm{H}$ heparin moieties (Boyle et al., 2010). cHABP 5501 is located at the beginning of the first EGF-like domain, containing at its $\mathrm{N}$ terminus the MSP1 secondary cleavage site that yields the MSP1 $19 \mathrm{kDa}$. It interacts with the band 3 (5ABC) sequence (residues 726-761) (Li et al., 2004).

\section{Parasite rolling and subsequent weak $R B C$ deformation mediated by GPI-anchored proteins and the EGF domain containing cHABPs}

Other MSPs have been putatively involved in morphologically defined rolling and RBC surface deformation (originally weak, later becoming very strong) (Figures 1F and H), i.e. MSP4, MSP8, MSP10 anchored to Mrz membrane via a GPI tail. Strikingly, together with other detergent-resistant membrane (DRM) proteins, Pf12 and Pf38 are GPI anchored, this being a very common characteristic of Mrz-derived proteins involved in RBC attachment (Figure 2B) (Sanders et al., 2005). This anchor is very rare in Spz-derived proteins or Mrz proteins involved in some other biological functions (Figure 2B).

The 272 amino acid-long $40 \mathrm{kDa}$ MSP-4 has only one cHABP (20494) located at the C-terminal end within the EGF-like domain (Rodriguez et al., 2008); 70 kDa MSP8 also contains an EGF-like domain including cHABP 26373 while MSP-10 cHABP 31132 is contained in a $61 \mathrm{kDa}$ fragment which is further processed into a $36 \mathrm{kDa}$ (Rodriguez et al., 2008). These 3 cHABPs, together with MSP-1 cHABP 5501, bind to RBC band 3 protein fragment $5 A B C$ (residues 726 to 761 ), thereby mediating initial stages during invasion. It has been suggested that such redundant sequences are used to escape immune pressure by switching just their $\mathrm{C}-\mathrm{C}$ residue location, due to amino acid sequence similarity in their EGF domains (Puentes et al., 2003).

The $48 \mathrm{kDa}$ soluble glutamate-rich MSP6 protein is cleaved at ${ }^{161} \mathrm{~S}$ in $\mathrm{HMIC}$ formation to yield an $\mathrm{MSP}_{36}$ fragment having great similarity with another member of the family, the MSP-3 protein. MSP6 ${ }_{36}$ forms a tetramer molecule in a tail-tail configuration mediated by CHABP 31191 which is 
non-covalently bound to the MSP $1_{38}$ fragment (Trucco et al., 2001).

351 amino acid-long $41 \mathrm{kDa}$ MSP7 is processed by removing the SS preceding a $38 \mathrm{kDa}$ polypeptide processed further on at residues ${ }^{176} \mathrm{Q}$ and ${ }^{177} \mathrm{~S}$ to generate $17 \mathrm{kDa} \mathrm{N}$-terminal and $22 \mathrm{kDa}$ C-terminal fragments. The latter is further processed to yield a $20.7 \mathrm{kDa}$ fragment and sequentially another $19 \mathrm{kDa}$ one, the latter binding to the MSP1 ${ }_{83}$ and $\mathrm{MSP}_{38}$ fragments to form the Mrz-derived HMIC (Pachebat et al., 2007). MSP-7 cHABPs 26114 and 26116 binding becomes totally abolished by RBC trypsin and chymotrypsin treatment, suggesting that these cHABPs could form a link between RBC and HMIC (Garcia et al., 2007).

Soluble 85 kDa MSP9 or acid basic repeat antigen (ABRA) participates in HMIC formation. cHABPs 2149, 2150 and 2153 are present in ABRA, 2149 having very high homology with a human cytosolic phospholipase $A_{2}$ active site (Table 1, highlighted in bold), so much so that this cHABP has dose-dependent haemolytic activity at low concentrations $(50 \mu \mathrm{M})$, while cHABPs 2150 and 2153 in the MSP9 $\triangle 1$ a (residues 77-241) recombinant fragment also bind to RBC band 3.0 in the $5 \mathrm{ABC}$ peptide ( $\mathrm{Li}$ et al., 2004; Rodriguez et al., 2008)

MSP-2, an abundant, intrinsically disordered membrane coat protein is anchored to Mrz surface via a GPI tail (Figure 2B). It has two allele forms (3D7 and FC27) having numerous variations, displaying $\mathrm{N}$ - and $\mathrm{C}$-terminal, highlyconserved regions flanking a hypervariable and unordered central region, tending to self-aggregate and form microfibrils (Adda et al., 2009). The only cHABP (4044) located in this protein's N-terminus has been found to have an amphipathic structure (Edmunson's wheel) between residues ${ }^{10} \mathrm{~T}$ to ${ }^{22} \mathrm{R}$ with amino acids ${ }^{12} \mathrm{I},{ }^{16} \mathrm{Y}$ and ${ }^{20} \mathrm{I}$ strongly and specifically interacting with dodecyl phosphocholine (DPC) and phosphatidyl inositol (PI) moieties on RBC membrane (MacRaild et al., 2012; Zhang et al., 2008), stressing this cHABP's very relevant role in aiding parasite invasion. MSP2, together with MSP4 (another GPI anchored protein), are the only complete, unprocessed MSPs carried inside the RBC (Boyle et al., 2014).

\section{cHABPs in strong RBC deformation promoting invasion}

It has been suggested that low potassium $\left(\mathrm{K}^{+}\right)$level in blood triggers $\mathrm{Mrz} \mathrm{Ca}{ }^{++}$release thereby activating microneme EBL (EBA-175, 140, 181, EBL-1) and rhoptry stored PfRh (Rh1, Rh2a, Rh2b, Rh4, Rh5) release (Singh et al., 2010); these proteins cooperate alternatively in a strong receptor-ligand type interaction to cope with RBC receptor genetic variability and immune pressure (Persson et al., 2008). These molecules have similar complementary and exquisitely redundant functions regulated by epigenetic factors (Cortes et al., 2007).

EBA 175 is the dominant ligand in the EBL family, having very similar $3 D$ structural and functional characteristics. It is synthesised as a $175 \mathrm{kDa}$ type 1 transmembrane protein, consisting of an SS followed by region II (RII) subdivided into two tandem Duffy binding-like (DBL) cysteine-rich related regions (F1 and F2) and regions III-IV linking RII to $\mathrm{RV}$ and $\mathrm{RVI}$, a small cysteine-rich region followed by a transmembrane region and a small cytoplasmic tail (Sim et al., 1990) (Table 1).

3D structural analysis of an RII recombinant fragment containing F1 (residues 8-282) and F2 (residues 297-603) regions (Tolia et al., 2005) has located cHABP 1783 in F2, where ${ }^{436} \mathrm{H}$ allowed dimerisation with a contralateral ${ }^{435} \mathrm{~V}$ in an inverted EBA-175 molecule, forming a "hand-shake-like" structure. Residues ${ }^{439} \mathrm{~K}$ and ${ }^{442} \mathrm{D}$ bound glycophorin $\mathrm{A}$ glycan 5 Neu5Ac1 via H-bonds. cHABP 1783 450W has also induced fold stabilisation at this site in the same RII and contained critical residue ${ }^{446} R$ establishing a salt bridge with ${ }^{30} \mathrm{D}$, thereby dramatically reducing RBC binding when ${ }^{446} \mathrm{R}$ is mutated (Rodriguez et al., 2008; Tolia et al., 2005).

cHABP 1779 is in close proximity to glycan 5 and 6 binding sites in F1 but does not interact directly with them (Salinas et al., 2014; Wanaguru et al., 2013a); antibodies against 1779 could therefore have exerted such influence by sterichindrance. It has been found recently that EBA-175 high activity binding to RBC has depended on both the DBL domains (F1 and F2) where 1779 and 1783 are located, such binding being inhibited and neutralised by antibodies but not galactose (Salinas and Tolia, 2014).

Region V cHABP 1815 contains a conserved sequence present in all EBL molecules where critical binding residues ${ }^{1258} \mathrm{R}$ and ${ }^{1265} \mathrm{~F}$ link $\mathrm{CHABP} 1815$ with 1818 in N-terminal region $\mathrm{VI}$ for mediating this protein's correct microneme trafficking (Sakura et al., 2013). Furthermore, EBA-175 cHABP 1818 has been located close to the cleavage site by rhomboid 4 protease, releasing EBA 175 to the milieu during invasion to allow $\mathrm{PV}$ formation. The complete recombinant EBA-175 ectodomain (PfEBA-175FL) binds RBC in a trypsin- and neuraminidase-sensitive manner, having greater affinity than the isolated RII fragment, thereby confirming the role of cHABPs located outside RII in RBC invasion (Rodriguez et al., 2008; Wanaguru et al., 2013a).

EBA-140 has a similar structure to EBA-175; however, the EBA-140 receptor-binding region contains two conserved Duffy binding-like (DBL) domains. Monomer EBA-140 has two glycan binding sites in the DBL, Pocket 1 (P1) and Pocket 2 (P2), contrasting with six glycan binding sites per dimer in PfEBA-175, suggesting that EBL proteins can create multiple binding pockets to accommodate different receptors (Lin et al., 2012; Malpede et al., 2013). EBA-140 ${ }^{541} D^{550} D^{551}$ in cHABP 26144 and ${ }^{618} \mathrm{Q}$ in cHABP 26147 are P2 components (Figure 1I), where cHABP $26144{ }^{556} \mathrm{Y}$ establishes $\mathrm{H}$-bonds with the glycophorin $\mathrm{C}$ glycan 2 sialic acid acetamide group (Malpede et al., 2013; Rodriguez et al., 2008). Mutations in ${ }^{556} Y$ have resulted in a $35.2 \%$ decrease in RBC binding ability while ${ }^{457} \mathrm{~N}$ in HABP 26139 P2 interacts with carboxyl group GlyC. Our corresponding peptides had very low binding capacity in EBA-140 P1 3D structure and critical ${ }^{182} \mathrm{Q}$ was followed by variable ${ }^{185}$, thereby altering RBC binding ability, which is why they were not considered in our studies (Malpede et al., 2013). Apart 
from sialic acid-dependent EBA-140 interaction with sialoproteins, it has also been found that this protein also strongly interacts with glycophorin $\mathrm{C}$ backbone residues; however, such specific receptor sites have not yet been described, even though cHABPs 26160 and 26170 located in this protein's region III and $\mathrm{V}$ could perform this function, since their binding to chymotrypsin-treated RBC became reduced by $>80 \%$ (Lin et al., 2012; Malpede et al., 2013; Rodriguez et al., 2008).

EBA-181 binds to a putative $W$ receptor suggested to be a band $4.110 \mathrm{kDa}$ fragment which is susceptible to neuraminidase and chymotrypsin treatment (Lanzillotti and Coetzer, 2006). cHABPs 30030 (located in this protein's binding domain) and 30051 are very susceptible to neuraminidase treatment ( $\geq 75 \%$ binding reduction), the latter being extremely susceptible to chymotrypsin treatment ( $\geq 92 \%$ binding reduction), completely fulfilling the enzymatic profile established for this molecule. cHABP 30060 has a non-canonical PEXEL motif ${ }^{683} \mathrm{RK}^{685} \mathrm{LF}^{687} \mathrm{~S}$, suggesting this protein's transport through membranes (Rodriguez et al., 2008).

It has been reported that the erythrocyte-binding-like 1 (EBL-1) protein's $\mathrm{D} 2$ domain or $\mathrm{F} 2$ region binds to a receptor in glycophorin $B$ which is resistant to trypsin but sensitive to chymotrypsin and neuraminidase (Mayer et al., 2009). The core binding site is contained within the 69 amino acid region, named $\mathrm{F} 2 \mathrm{i}$ (residues ${ }^{601} \mathrm{C}$ to ${ }^{669} \mathrm{~V}$ ), where cHABPs 29923 and 29924 are completely located (Li et al., 2012; Rodriguez et al., 2008). The cHABP 30018 receptor is extremely susceptible to trypsin (65\% binding reduction) and chymotrypsin (95\% reduction) and is located 10 residues upstream rhomboid 4 cleavage site and the Cys-rich region; another binding site could thus exist in a different region, as in the other EBL proteins (Table 1).

The MAEBL 243 kDa hybrid protein expressed in Mrz and Spz rhoptries, having a similar structure to other EBLs, has a carboxyl terminal (R6) cysteine-rich domain, duplicated AMA-1-like domains (D1 and D2) instead of a DBL domain in R2 (Ghai et al., 2002). AMA-1-like domains have cell binding abilities where cHABPs 30212 and 30220 have been found in the M2 domain, the main RBC binding domain (Ghai et al., 2002; Rodriguez et al., 2008). cHABP 30195 in M1 is very susceptible to chymotrypsin. A MAEBL isoform containing the $\mathrm{C}$-terminal transmembrane domain (ORF1) is essential for Spz invasion of the Anopheles mosquito's salivary glands and cHABP 30276 (residues 2021-2040) is located in this region containing critical residues ${ }^{2021} \mathrm{E},{ }^{2030} \mathrm{Y},{ }^{2038} \mathrm{E}$ and ${ }^{2039} \mathrm{E}$ (Rodriguez et al., 2008; Saenz et al., 2008).

\section{The role of the PfRh family in RBC invasion}

This family of rhoptry proteins, having high homology with $P$. vivax reticulocyte binding proteins (Rh or RBL), includes Rh1, 2a, 2b and 4, having very high molecular weights ( 350kDa) (Figure 2B and Table 1), except for the recently described Rh5 $(63 \mathrm{kDa})$. PfRhs are recognised by their interactions with receptors having variable susceptibility to enzymes, specifically neuraminidase where the Rh1 receptor is sialic acid dependent (SAD) and Rh2b and Rh4 are sialic acid independent (SAI) (DeSimone et al., 2009; Stubbs et al., 2005).

\section{Sialic acid dependence for triggering functional $\mathrm{Ca}^{++}$}

The $358 \mathrm{kDa}$ Rh1 SAD protein, processed into a $240 \mathrm{kDa}$ $\mathrm{N}$-terminal and $120 \mathrm{kDa} \mathrm{C}$ terminal fragments before $\mathrm{Mrz}$ release, contains $8 \mathrm{cHABPs}$ whose interaction with neuraminidase-treated RBC becomes completely abolished (Arevalo-Pinzon et al., 2013). cHABP 36389, which is extremely susceptible to RBC trypsin treatment, is located in RII-3, thereby blocking RBC invasion (Gao et al., 2008). Intermediate binding ( $1.5 \%$ specific binding) HABPs 36396 and 36397 contain the ${ }^{757}$ TDEKINDYLEE ${ }^{767}$ sequence triggering the calcium $\left(\mathrm{Ca}^{++}\right)$signal during $\mathrm{RBC}$ invasion (Arevalo-Pinzon et al., 2013; Gao et al., 2013). cHABP 36482 has been found in the $\sim 10 \mathrm{kDa}$ portion, remaining attached to the parasite when the $120 \mathrm{kDa}$ fragment in the C-terminus has been cleaved, the $10 \mathrm{kDa}$ part being carried into ring stage RBC (Triglia et al., 2009).

\section{Sialic acid independence}

PfRh4 is a $220 \mathrm{kDa}$ protein which releases a $\sim 160 \mathrm{kDa}$ fragment when undergoing proteolytic processing (Triglia et al., 2009). The Rh4 region which binds to a receptor on RBC consists of a $30 \mathrm{kDa}$ fragment $\left({ }^{328} \mathrm{~N}\right.$ to $\left.{ }^{588} \mathrm{D}\right)$ where cHABP 34195 is found (Garcia et al., 2010; Gaur et al., 2007). PfRh4 erythrocyte-binding ability has been shown to be SAI and trypsin and chymotrypsin sensitive, thereby agreeing with RBC complement receptor 1 (CR1) binding to the most membrane-distal of the 30 complement control proteins $(\mathrm{CCP})$ domain, where CCP1 residues ${ }^{7} \mathrm{H},{ }^{9} \mathrm{~L},{ }^{18} \mathrm{~N}$ and ${ }^{20} \mathrm{~F}$ form the PfRh4-binding site (Park et al., 2014). cHABPs $34195,34215,34224$ and 34243 binding has been seen to be extremely sensitive to treatment with trypsin and chymotrypsin (Garcia et al., 2010).

\section{Rh2a, Rh2b cooperate with Rh4 for efficient SAl invasion \\ $P$. falciparum strains express different proteins due to the complexity of the host cell-microbe interaction, depending on the RBC receptor's genetic makeup.}

Rh2a ( 360kDa) and Rh2b have great sequence similarity, where Rh2a is cleaved at its N-terminus to release a 90 $\mathrm{kDa}$ fragment and another $270 \mathrm{kDa}$ one, this being further processed into a $130 \mathrm{kDa}$ portion and a $140 \mathrm{kDa}$ fragment which is then transported to the TJ where it has been suggested that it plays a role in helping Mrz enter RBC (Gunalan et al., 2011). Enzymatic treatment has rendered the $\mathrm{N}$-terminus fragment susceptible to neuraminidase, while $270 \mathrm{kDa}$ and $140 \mathrm{kDa}$ are extremely susceptible to chymotrypsin. cHABP 26835 is exclusive to Rh2a while 26529 and 26534 are exclusive to C-terminus region Rh2b where 26534 containing the ${ }^{3134} \mathrm{RT}^{3136} \mathrm{LD}^{3138} \mathrm{E}$ PEXEL motif is located 50 residues upstream the cleavage site by a rhomboid protease, while cHABP 26818 is common to both Rh2a and Rh2b (Table 1). The critical RBC binding residues for all of them have been identified by glycine analogue scanning (Rodriguez et al., 2008). Rh2b antibodies do not inhibit Mrz invasion when EBA-181 is 
absent, suggesting that these two proteins cooperate during invasion (Lopaticki et al., 2011)

\section{cHABPs involved in pore formation}

The soluble $\sim 63 \mathrm{kDa}$ Rh5 protein is an atypical integrant of the Rh family which interacts with two proteins located in the micronemes: $P$. falciparum Rh5 interacting protein (PfRipr) and GPI-anchored cysteine-rich protective antigen (CyRPA) (Reddy et al., 2015). This complex mediates pore formation through Rh5 binding to basigin and RBC from different species (Wanaguru et al., 2013b). A 45 kDa fragment observed in parasite lysate specifically interacts with CD147 (basigin) a receptor protein expressed on RBC membrane and other cells (Crosnier et al., 2011). The contact residues between basigin and Rh5 are concentrated between residues 197 to 448 where cHABP 36727 is located, containing ${ }^{207} \mathrm{D}$ which, together with ${ }^{362} \mathrm{E} /$ $\mathrm{D}$ located in peptide 36735 , contact the basigin C-terminal domain. Furthermore, cHABP 36727 is located one residue downstream of those contacting the basigin amino terminal extreme (Wright et al., 2014). Point mutations at Rh5 cHABP 36727 residue I204K have been involved in binding activity and specie-specific invasion of Aotus monkey RBC (Arevalo-Pinzon et al., 2012). cHABP 36739 (unpublished results) is located in the Rh5 C-terminal fragment (residues ${ }^{447} \mathrm{WRT}^{449}$ ) and interacts with basigin (Arevalo-Pinzon et al., 2012).

\section{Tight junction formation}

Electron microscopy has shown that Mrz reorient their apical tip after initial rolling to face erythrocyte surface to form an electron-dense structure moving rapidly inside RBC (i.e. TJ formation), partly mediated by microneme apical membrane antigen 1 (AMA-1) (Mitchell et al., 2004) (Figure $1 \mathrm{E}$ and $\mathrm{F}$ ) and the rhoptry neck protein 2 (RON2) (Collins and Blackman, 2011; Giovannini et al., 2011).

The bulk of $83 \mathrm{kDa}$ precursor AMA1 is formed by the ectodomain, divided into a pro-domain and three structural domains (I, II, III) defined by a pattern of 16 conserved cysteines contributing 8 disulphide bonds (Hodder et al., 1996) and a transmembrane helix followed by a cytoplasmic C-terminal tail (Figure 2 and Table 1). Domains I and II are similar and belong to the plasminogen apple nematode (PAN) super-family, forming a protein fold having a long hydrophobic trough surrounded by major polymorphic sites in domain I and dimorphic residues in domains II and III involved in receptor binding (Bai et al., 2005).

Domain I ${ }^{134} \mathrm{D}$ and ${ }^{143} \mathrm{R}$ cHABP 4313 establishes two $\mathrm{H}$ bonds with cHABP $4325{ }^{390} \mathrm{Y}^{391} \mathrm{~K}$ (domain II) to form a trough or channel where a still unrecognised receptor binds (Patarroyo et al., 2011). cHABP 4337 contains the complete intracytoplasmic domain $\left({ }^{603} \mathrm{~W}\right.$ to $\left.{ }^{622} \mathrm{Y}\right)$, including ${ }^{610} \mathrm{~S}$ and ${ }^{613} \mathrm{~T}$ phosphorylation sites which are critical in AMA1 invasion, and ${ }^{622} Y$ the aldolase binding residue (Leykauf et al., 2010). AMA-1 is also involved in Spz invasion of hepatocytes and it has been shown that cHABP 4310 forms a niche stabilised by $\mathrm{H}$-bonds to bind to HepG2 cells (Patarroyo et al., 2011; Schussek et al., 2013); it is topologically very close to CHABP 4332 in domain III (one in front of the other). cHABP 4332 is cleaved between ${ }^{517} \mathrm{~T}^{518} \mathrm{~S}$ while two residues downstream $\left({ }^{94} \mathrm{~F}^{95} \mathrm{~S}\right) \mathrm{cHABP}$ 4310 is cleaved, these being the only two fragments remaining as stubs entering the RBC. Only the cytoplasmic, transmembrane region and an adjacent 29 residue membrane fragment can be detected in ring-stage parasites (Howell et al., 2001). cHABP 4332 in the P. yoelii orthologous system containing region was able to induce sterilising protective immunity against $\mathrm{Spz}$ challenge (Schussek et al., 2013).

\section{The role of iRBC surface cHABPs in severe malaria}

It has been postulated that $P$. falciparum parasites have developed a series of highly polymorphic molecules and clonal antigenic variation on iRBC membrane for binding different cell types to escape spleen surveillance and clearance. iRBC accumulation in different organs is a key factor in this disease's pathogenesis due to the microvascular obstruction or inflammation induced by it. Virulence-associated proteins would include Plasmodium falciparum erythrocyte membrane protein 1 (PfEMP-1), the subtelomeric variable open reading frame family (STEVOR), early transcribed membrane protein (ETRAMP), ring exported (REX) protein, surfaceassociated interspersed gene family (SURFIN) (collectively known as variable surface antigens: VSA). Some, like PfEMP-1, are assembled and anchored to RBC cytoskeleton molecules spectrin and actin by molecule like knob-associated histidine-rich protein (KAHRP) which, together with VSA, forms a RBC membrane rigid structure (i.e. knobs), inducing reduced membrane deformability (Spillman et al., 2015).

PfEMP-1 is a $200-350 \mathrm{kDa}$ protein which is encoded by the differentially expressed 59 var multigene family (including 56 var genes and 3 small var genes) where each parasite produces a single PfEMP-1 variant per iRBC (Zhang et al., 2014). This protein mediates adhesion to host cells and molecules like uninfected RBC, ABO blood groups, vascular endothelial, syncytiotrophoblast placental cells, ICAM, CD31 and CD36 molecules (Salanti et al., 2004; Smith et al., 2013; Vigan-Womas et al., 2012).

PfEMP-1 has an extracellular region consisting of 2 to 9 domains which are extremely variable regarding amino acid sequence, composition and length (Figure 2B and Table 1). These domains include an $\mathrm{N}$-terminal segment (NTS), a Duffy binding-like (DBL) $1 \alpha$ domain, a cysteine inter-domain region (CIDR) $\alpha 1$ (all forming the head structure) and DBL2X, C2, DBL3X-DBL $4 \varepsilon$ to $7 \varepsilon$ domains followed by a transmembrane region (TM) and an intracytoplasmic acidic terminal segment (ATS) inserted into iRBC membrane (Smith et al., 2013).

The thousands of PfEMP-1 sequences have revealed this molecule's tremendous variability, having very few and very short conserved sequences. Our approach for identifying cHABPs, working with the Dd2 var 1 clone able to bind C32 cells and RBC, has revealed just two HABP pairs where DBL $1 \alpha$ cHABP 6510 establishes an $\mathrm{H}$-bond between ${ }^{139} \mathrm{C}$ and ${ }^{168} \mathrm{E}$ from HABP 6512 binding to $\mathrm{A} 1$ blood group $\alpha-1,3$ linked $\mathrm{N}$-acetyl galactosamine (Patarroyo et al., 2014). 
DBL3X cHABP $6573{ }^{1268} \mathrm{R}$ establishes an $\mathrm{H}$-bond with HABP $6583{ }^{1456} \mathrm{E}$ and HABP $6583{ }^{1257} \mathrm{~W}$ and ${ }^{1261} \mathrm{E}$ with HABP $6584{ }^{1511} \mathrm{Y}$ and ${ }^{1518} \mathrm{E}$, present in the same region, creating a niche to accommodate chondroitin sulphate proteoglycans (CSPG). Strikingly, cHABP 6510 and 6573 have the conserved GACXPXRRXXLC motif, being one of the few conserved sequences having a characterised biological function (Patarroyo et al., 2014). The strategy for tackling this molecule's tremendous amino acid sequence polymorphism will involve a completely different methodology, based on in-depth 3D structural knowledge working with restricted configuration peptides (Calvo et al., 2003), pseudopeptides or mimotopes (Lozano et al., 2013).

The cytoadherence-linked asexual gene (clag9), encoding at least 9 exons, belongs to the high molecular weight RhopH complex (containing clag/RhopH1, RhopH2 and RhopH3) expressed in blood stages (Trenholme et al., 2000) (Figure 2B and Table 1). CLAG-9 is implicated in cytoadherence, binding to CD36 (the most widespread receptor on endothelial cells) and involved in trafficking of EMP-1 or initial remodelling of host red blood cells so that these proteins can be trafficked to the appropriate location (Gupta et al., 2015; Trenholme et al., 2000). CLAG-9 has cHABPs 33815,33840 and 33846 where enzymatic treatment of RBC with trypsin and chymotrypsin has significantly reduced $\mathrm{CHABP}$ specific binding, suggesting that the $\mathrm{CHABP}$ receptor on $\mathrm{RBC}$ membrane has a protein composition (Pinzon et al., 2010).

KAHRP, one of the classical members of the transportome concept, is a $80-100 \mathrm{kDa}$ molecule; it consists of an $\mathrm{N}$ terminal histidine-rich domain (region $\mathrm{I}$, residues 41-300), a central lysine-rich domain (region II, residues 301-480) and a C-terminal decapeptide repeat domain (region III, residues 481-660). The classical PEXEL motif ${ }^{54} R T^{56} L A^{58} Q$ is present in region $\mathrm{I}$, while cHABP 6786 (residues $381-400$ ) is located in region II.

HRPII is $100 \mathrm{kDa}$, is stored in Maurer's clefts and is assembled on iRBC membrane where cHABP 6800 (residues 24-43) is located two residues before a canonical PEXEL motif $\left({ }^{45} R L^{47} \mathbf{L} H^{49} E\right)$ (Lopez-Estrano et al., 2003), suggesting this cHABP's exposure on iRBC membrane could be an important target for vaccine development.

The STEVOR protein family encodes $\sim 30$ stevor genes organised similarly to rifin genes where exon I encodes SS and exon II encodes a family of $34 \mathrm{kDa}$ integral proteins having two transmembrane domains flanking a hypervariable region located in the apical end of the Mrz and transported to iRBC membrane (Blythe et al., 2008). STEVOR transcription peaks at 22-32 $\mathrm{h}$ in late trophozoites and early schizonts and has been unambiguously demonstrated to be inserted into iRBC membrane (Niang et al., 2009). cHABP 30561 (residues 41-60) has a PEXEL motif in ${ }^{44} R R^{46} L A^{48} E$; it is highly susceptible to erythrocyte binding after trypsin treatment of RBC and cHABP 30567 (residues 161-180), which is extremely sensitive to neuraminidase and trypsin treatment, is located in the $\mathrm{N}$ terminal portion close to the transmembrane region and binds glycophorin $\mathrm{C}$ to mediate Mrz invasion of $\mathrm{RBC}$ and rosseting by iRBC (Bachmann et al., 2015; Garcia et al., 2005; Niang et al., 2014; Sanyal et al., 2012).

Ring exported (REX) proteins are another VSA protein family, consisting of a family of 4 transcripts (REX1, 2, 3 and 4) in all stages of intra-erythrocyte development, mainly expressed $\sim 20$ hours (early rings) after RBC invasion (Hawthorne et al., 2004; Spielmann et al., 2006). REX4 (a 26kDa protein), containing cHABP 33965 (residues 61-80), is highly susceptible to chymotrypsin and trypsin treatment of RBC and displays a PEXEL motif 10 residues upstream the CHABP. REX3 has the classical PEXEL motif ${ }^{45} \mathrm{RN}^{47} \mathrm{LS}^{49} \mathrm{E} 25$ residues downstream cHABP 33945. PEXEL negative exported protein (PNEP) REX 2 displays cHABP 33782 which is extremely susceptible to neuraminidase treatment of $\mathrm{RBC}(100 \%$ reduction in binding) (Garcia et al., 2009a).

PEXEL motifs (RxLXE/D/Q) are cleaved by an endoplasmic reticulum (ER) resident plasmepsin $V$ after conserved $L$. They are further acetylated to allow these proteins' maturation and solubility and transport from the parasite's $\mathrm{PV}$ and parasitophorous vacuole membrane (PVM) to host cells which, together with proteins lacking the PEXEL motif called PEXEL negative exported proteins (PNEP), are transported to the Maurer's clefts and peripheral membrane (Goldberg, 2012; Gruring et al., 2012).

Likewise, among the 13 family members of early transcribed membrane proteins (eTRAMP), eTRAMP 10.2 displays cHABPs 33882 (residues 41-60) containing a PEXEL motif in residues ${ }^{52} \mathrm{RN}^{54} \mathrm{LI}{ }^{56} \mathrm{~L}$ and 33891 which is extremely susceptible to neuraminidase treatment of RBC ( $0 \%$ binding) and trypsin ( $9 \%$ binding activity) (Garcia et al., 2009a).

These cHABPs also represent excellent targets for $P$. falciparum blood stage vaccine development, being so relevant in protein transport and expressed on iRBC during early $P$. falciparum parasite development stages.

\section{Some other critical functions associated with cHABPs}

$P$. falciparum proteins simultaneously display functions different to receptor-ligand interactions, such as serine repeat antigen (SERA) 5 (one of the 9 members of the SERA family). This $114 \mathrm{kDa}$ protein is processed during Mrz release into a $47 \mathrm{kDa} \mathrm{N}$-terminal, a $56 \mathrm{kDa}$ inner region having serine-like protease activity region and a 18 $\mathrm{kDa}$ C-terminal portion. cHABP 6737 is located in the 56 $\mathrm{kDa}$ inner region 18 residues downstream (i.e. the subtilisin-1 (SUB1) cleavage site), while cHABPs 6746 and 6754 are more centrally located (Rodriguez et al., 2008). The 3D structure of a recombinant fragment has revealed a non-canonical serine protease active site (Hodder et al., 2009), stabilised by $2 \mathrm{H}$-bonds between cHABP $6746{ }^{588} \mathrm{~S}$ and $6754{ }^{755} \mathrm{H}^{756} \mathrm{~A}$, suggestive of this papain-like cysteine protease's active site. Replacing $S^{596} \mathrm{C}$ in the recombinant protein led to such modification inducing clear cysteine protease enzymatic activity (Stallmach et al., 2015). Further cleavage of the $56 \mathrm{kDa}$ located towards the Cterminus liberates a $6 \mathrm{kDa}$ fragment where our 6758 cHABP is completely included. The last $\mathrm{C}$-terminal residues 
of this cHABP inhibit this protein's enzymatic activity in an allosteric-like interaction; molecular docking studies have suggested this peptide binds to the SERA-5 active site (Kanodia et al., 2014).

\section{The CLAG 3.2 protein}

Plasmodium surface anion channel (PSAC) linked to $P$. falciparum CLAG 3.2 mediates $\mathrm{IRBC}$ nutrition, contributing towards ion and nutrient entry. It has been clearly demonstrated that a couple of amphipathic sequences (Edmunson's wheels) in one of this $142 \mathrm{kDa}$ protein's transmembrane domains (adjacent to extracellular motifs) are involved in malaria parasite nutrient channel formation (Nguitragool et al., 2014). These sequences, traversing the RBC membrane, have been located in the C-terminal area, distal to the hypervariable region limits spanning ${ }^{1100} \mathrm{~S}$ to ${ }^{1120} \mathrm{Y}$ and ${ }^{1200} \mathrm{~F}$ to ${ }^{1220} \mathrm{Y}$. cHABP $30428\left({ }^{1160} \mathrm{~L}\right.$ to $\left.{ }^{1180} \mathrm{Q}\right)$ has been located in between these two regions in the CLAG 3.2 surface exposed region. cHABP 30421 binds with very high capacity to both $\mathrm{C} 32$ and RBC (Rodriguez et al., 2008).

\section{The RAMA protein}

This late ring, early trophozoite and immature schizont expressed rhoptry associated membrane antigen (RAMA), synthesised as a $170 \mathrm{kDa}$ precursor, is cleaved to produce a $60 \mathrm{kDa}$ C-terminal fragment anchored to the membrane by a GPI tail via a 25 mer hydrophobic sequence (Topolska et al., 2004). It contains cHABP 33460, located in the histidine ATPase region. RAMA has a PEXEL motif in cHABP $34426\left({ }^{91} \mathrm{RI}^{93} \mathrm{LY}{ }^{95} \mathrm{D}\right)$ before the first acidic domain, suggesting that this protein is transported through membranes to iRBC surface via this sequence (Pinzon et al., 2008a).

\section{The RhopH3 protein}

It has been very recently shown that the $110 \mathrm{kDa}$ RhopH3 protein encoded by seven exons is involved in HMIC formation. This rhoptry's molecule, appearing 30 hours after invasion, binds to $\mathrm{RBC}$ band 3 in the $5 \mathrm{ABC}$ region through a C-terminal portion (residues 734-865) containing cHABPs 33580 and 33581 (extremely susceptible to trypsin treatment) and to the MSP1 $1_{19}$ fragment anchored by a GPI tail to the RBC membrane, suggesting that these cHABPs are involved in parasite rolling and initial steps of RBC invasion (Baldwin et al., 2014; Pinzon et al., 2008b; Ranjan et al., 2011).

\section{Pf12, Pf41 and Pf38}

The multistage Cys6 family contains some GPI anchored proteins; 6 notably conserved Cys residues form similar domains. Pf12 cHABP 33633 establishes $6 \mathrm{H}$-bonds between ${ }^{271}{ }^{R L P}{ }^{273}$ residues with intermediate conserved binding HABP $33631{ }^{218} \mathrm{ND}^{219}$ (Arredondo et al., 2012) to generate a niche where an extremely sensitive neuraminidase, trypsin and chymotrypsin receptor binds (Garcia et al., 2009b). Likewise, the Pf38 GPI anchored DRM protein contains cHABP 33645 having the same extreme enzymatic susceptibility. Pf41 without a GPI tail establishes $3 \mathrm{H}$-bonds between cHABPs 33713 and 33715 and GPI anchored Pf12, having antiparallel orientation to be presented to the host cell (Tonkin et al., 2013). There is a controversy about these proteins' role in RBC invasion.

\section{PTRAMP}

Plasmodium thrombospondin-related apical merozoite protein (PTRAMP) is located in the micronemes and subsequently becomes relocated to Mrz surface. This protein contains a TSR domain within its ectodomain and has a cytoplasmic domain which has been shown to weakly interact with aldolase (Thompson et al., 2004). As attempts to delete it have failed, it appears to have an essential and conserved biological function (Thompson et al., 2004). cHABP 33405, located in the PTRAMP aminoterminal region, contained a PEXEL-like sequence in its $\mathrm{C}$ terminal portion whilst HABP 33413 was located in the protein's central region just before the TSR domain (Calderon et al., 2008).

\section{Conclusions}

Thorough amino acid level analysis of 49 (13 Spz- and 36 Mrz-derived) of the most important proteins involved in $P$. falciparum infection during the last 25 years has demonstrated that many cHABPs perform very relevant biological functions, such as Spz gliding motility, cell traversal activity, invasion of hepatocytes and reproduction in the liver cells (Ferguson et al., 2014; Ishino et al., 2004; Kariu et al., 2006; Song et al., 2012; Sultan et al., 1997). Other functions are directly mediated by Mrz in RBC invasion as elegantly documented by (Weiss et al., 2015) where the sequence of events like Mrz rolling on RBC surface, strong erythrocyte deformation and invasion, pore and $\mathrm{TJ}$ formation, expression on $\mathrm{iRBC}$, ion and nutrient transport are associated with these cHABPs.

This manuscript has provided, for the first time, a deep molecular analysis (at the atomic level when possible) of these cHABPs' fundamental biological functions in host-cell microbe interactions and parasite survival, making them excellent targets for multi-epitope, multistage, minimal subunit based, chemically synthesised vaccine development and some of them even for drug design.

Further work with new methodologies, like the very recently described RBC protein binding Mrz ligands such as basigin allowing recognition of Rh5 as a key molecule in Mrz invasion (Crosnier et al., 2011; Wright et al., 2014) and complement-regulatory protein CD55 (a receptor for bacterial and viral pathogens (Coyne and Bergelson, 2006; O'Brien et al., 2008) whose absence did not enable parasite invasion when EBA-140, EBA-175, EBA-181, Rh1, Rh2a or Rh2b were deleted (Egan et al., 2015), blood group A binding RIFINs proteins, deeply involved in severe malaria (Goel et al., 2015), has suggested that some cHABPs present in proteins for which direct functional activity has not yet been assigned could be directly involved in invasion and other pathogenic mechanisms regarding this very complex parasite, thereby strongly supporting our functional-biological methodology as a way of identifying potential vaccine or drugs targets. Furthermore, these molecules interact in a very synchronic orchestrated way (LaCount et al., 2005; Weiss et al., 2015; Wuchty, 2007), suggesting that their blocking by immune 
reactions or drugs could impede the cascade of events leading to host cell invasion; however, future analysis needs further work.

This approach, the first of this kind, has been further supported by the disappointing results which have recently been reported regarding the recombinant RTS,S/ASO1 malaria vaccine candidate tested on 15,459 children and infants who were followed-up for $\sim 4$ years (Rts, 2015) yielding $28.3 \%$ to $36.3 \%$ protective efficacy against clinical malaria and only $17.3 \%$ to $10.3 \%$ protection against severe malaria defining a malaria case as any individual with fever $>37.5^{\circ} \mathrm{C}$ and more than 5000 parasites/ $\mu \mathrm{L}$ (1 infected RBC $x 1000$ RBC), clearly showing that this is not the appropriate approach for vaccine development. Only one of our CSP-1 functionally-relevant cHABPs (4397, shadowed in Table 1) is present in this vaccine candidate's amino acid sequence, without any further modification, stressing once again the tremendous complexity of the parasite's lifecycle and the impossibility of killing it with a single "magic bullet". Such failure and many more frustrating malaria vaccine human trials involving thousands of people reinforce the importance of the basic work developed by many laboratories throughout the world for decades now, trying to understand this tricky parasite's biology at its deepest level to ensure a logical and rational methodology for effective vaccine development.

Based on large sero-epidemiological results obtained with complex microarray technologies, some malaria experts involved in vaccine development have recently suggested that mixtures of some of the most relevant proteins (whether complete or recombinant fragments) could be the answer to developing a fully complete vaccine against this deadly disease (Boes et al., 2015; Osier et al., 2014). Nevertheless, it is clear that all the molecules required from this complex parasite with tremendous genetic polymorphism in the same molecule, with multiple invasion mechanism, as shown here, with redundant protein systems to evade immune pressure, plus human genetic variability, might complicate such approach.

Therefore, an appropriate mixture of all, or most, of the aforementioned very short HABPs (20 mer long), when properly modified (mHABPs), should lead to a multiepitope, multistage, minimal subunit-based, fully protective, complete, definitive synthetic vaccine against malaria opening the gate for the development of new vaccines against scourging diseases for humankind, malaria being one of them, as we have been systematically suggesting for more than 30 years now.

\section{Acknowledgements}

We would like to Jason Garry for translating and reviewing this manuscript. This work was financed by the Colombian Science, Technology and Innovation Department (COLCIENCIAS) through contracts RC \# 0309-2013.

\section{Conflict of interest disclosure}

The authors declare no competing financial interest.

\section{References}

Adda, C.G., Murphy, V.J., Sunde, M., Waddington, L.J., Schloegel, J., Talbo, G.H., Vingas, K., Kienzle, V., Masciantonio, R., Howlett, G.J., et al. (2009). Plasmodium falciparum merozoite surface protein 2 is unstructured and forms amyloid-like fibrils. Mol Biochem Parasitol 166, 159-171.

Amino, R., Giovannini, D., Thiberge, S., Gueirard, P., Boisson, B., Dubremetz, J.F., Prevost, M.C., Ishino, T., Yuda, M., and Menard, R. (2008). Host cell traversal is important for progression of the malaria parasite through the dermis to the liver. Cell Host Microbe 3, 88-96.

Arevalo-Pinzon, G., Curtidor, H., Munoz, M., Patarroyo, M.A., Bermudez, A., and Patarroyo, M.E. (2012). A single amino acid change in the Plasmodium falciparum RH5 (PfRH5) human RBC binding sequence modifies its structure and determines species-specific binding activity. Vaccine 30, 637-646.

Arevalo-Pinzon, G., Curtidor, H., Munoz, M., Patarroyo, M.A., and Patarroyo, M.E. (2011). Synthetic peptides from two Pf sporozoite invasion-associated proteins specifically interact with HeLa and HepG2 cells. Peptides 32, 1902-1908.

Arevalo-Pinzon, G., Curtidor, H., Munoz, M., Suarez, D., Patarroyo, M.A., and Patarroyo, M.E. (2013). Rh1 high activity binding peptides inhibit high percentages of Plasmodium falciparum FVO strain invasion. Vaccine 31, 1830-1837.

Arredondo, S.A., Cai, M., Takayama, Y., MacDonald, N.J., Anderson, D.E., Aravind, L., Clore, G.M., and Miller, L.H. (2012). Structure of the Plasmodium 6-cysteine s48/45 domain. Proc Natl Acad Sci U S A 109, 6692-6697.

Bachmann, A., Scholz, J.A., Janssen, M., Klinkert, M.Q., Tannich, E., Bruchhaus, I., and Petter, M. (2015). A comparative study of the localization and membrane topology of members of the RIFIN, STEVOR and PfMC-2TM protein families in Plasmodium falciparuminfected erythrocytes. Malar J 14, 274.

Bai, T., Becker, M., Gupta, A., Strike, P., Murphy, V.J., Anders, R.F., and Batchelor, A.H. (2005). Structure of AMA1 from Plasmodium falciparum reveals a clustering of polymorphisms that surround a conserved hydrophobic pocket. Proc Natl Acad Sci U S A 102, 12736-12741.

Baldwin, M., Yamodo, I., Ranjan, R., Li, X., Mines, G., Marinkovic, M., Hanada, T., Oh, S.S., and Chishti, A.H. (2014). Human erythrocyte band 3 functions as a receptor for the sialic acid-independent invasion of Plasmodium falciparum. Role of the RhopH3-MSP1 complex. Biochim Biophys Acta 1843, 2855-2870.

Blackman, M.J., and Holder, A.A. (1992). Secondary processing of the Plasmodium falciparum merozoite surface protein-1 (MSP1) by a calcium-dependent membrane-bound serine protease: shedding of MSP133 as a noncovalently associated complex with other fragments of the MSP1. Mol Biochem Parasitol 50, 307-315.

Blythe, J.E., Yam, X.Y., Kuss, C., Bozdech, Z., Holder, A.A., Marsh, K., Langhorne, J., and Preiser, P.R. (2008). Plasmodium falciparum STEVOR proteins are highly expressed in patient isolates and located in the surface 
membranes of infected red blood cells and the apical tips of merozoites. Infect Immun 76, 3329-3336.

Boes, A., Spiegel, H., Voepel, N., Edgue, G., Beiss, V., Kapelski, S., Fendel, R., Scheuermayer, M., Pradel, G., Bolscher, J.M., et al. (2015). Analysis of a Multicomponent Multi-stage Malaria Vaccine CandidateTackling the Cocktail Challenge. PLoS One 10, e0131456.

Boyle, M.J., Langer, C., Chan, J.A., Hodder, A.N., Coppel, R.L., Anders, R.F., and Beeson, J.G. (2014). Sequential processing of merozoite surface proteins during and after erythrocyte invasion by Plasmodium falciparum. Infect Immun 82, 924-936.

Boyle, M.J., Richards, J.S., Gilson, P.R., Chai, W., and Beeson, J.G. (2010). Interactions with heparin-like molecules during erythrocyte invasion by Plasmodium falciparum merozoites. Blood 115, 4559-4568.

Bozdech, Z., Llinas, M., Pulliam, B.L., Wong, E.D., Zhu, J., and DeRisi, J.L. (2003). The transcriptome of the intraerythrocytic developmental cycle of Plasmodium falciparum. PLoS Biol 1, E5.

Buscaglia, C.A., Coppens, I., Hol, W.G., and Nussenzweig, V. (2003). Sites of interaction between aldolase and thrombospondin-related anonymous protein in plasmodium. Mol Biol Cell 14, 4947-4957.

Calderon, J.C., Curtidor, H., Gonzalez, O., Cifuentes, G., Reyes, C., and Patarroyo, M.E. (2008). High affinity interactions between red blood cell receptors and synthetic Plasmodium thrombospondin-related apical merozoite protein (PTRAMP) peptides. Biochimie 90, 802-810.

Calvo, J.C., Choconta, K.C., Diaz, D., Orozco, O., Bravo, M.M., Espejo, F., Salazar, L.M., Guzman, F., and Patarroyo, M.E. (2003). An alpha helix conformationally restricted peptide is recognized by cervical carcinoma patients' sera. J Med Chem 46, 5389-5394.

Calvo, M., Guzman, F., Perez, E., Segura, C.H., Molano, A., and Patarroyo, M.E. (1991). Specific interactions of synthetic peptides derived from $P$. falciparum merozoite proteins with human red blood cells. Pept Res 4, 324-333.

Collins, C.R., and Blackman, M.J. (2011). Apicomplexan AMA1 in host cell invasion: a model at the junction? Cell Host Microbe 10, 531-533.

Coppi, A., Natarajan, R., Pradel, G., Bennett, B.L., James, E.R., Roggero, M.A., Corradin, G., Persson, C., Tewari, R., and Sinnis, P. (2011). The malaria circumsporozoite protein has two functional domains, each with distinct roles as sporozoites journey from mosquito to mammalian host. J Exp Med 208, 341-356.

Cortes, A., Carret, C., Kaneko, O., Yim Lim, B.Y., Ivens, A., and Holder, A.A. (2007). Epigenetic silencing of Plasmodium falciparum genes linked to erythrocyte invasion. PLoS Pathog 3, e107.

Coyne, C.B., and Bergelson, J.M. (2006). Virus-induced Abl and Fyn kinase signals permit coxsackievirus entry through epithelial tight junctions. Cell 124, 119-131.

Crosnier, C., Bustamante, L.Y., Bartholdson, S.J., Bei, A.K., Theron, M., Uchikawa, M., Mboup, S., Ndir, O., Kwiatkowski, D.P., Duraisingh, M.T., et al. (2011). Basigin is a receptor essential for erythrocyte invasion by Plasmodium falciparum. Nature 480, 534-537.
Curtidor, H., Arevalo-Pinzon, G., Bermudez, A., Calderon, D., Vanegas, M., Patino, L.C., Patarroyo, M.A., and Patarroyo, M.E. (2012). Binding activity, structure, and immunogenicity of synthetic peptides derived from Plasmodium falciparum CelTOS and TRSP proteins. Amino Acids 43, 365-378.

Curtidor, H., Vanegas, M., Alba, M.P., and Patarroyo, M.E. (2011). Functional, immunological and three-dimensional analysis of chemically synthesised sporozoite peptides as components of a fully-effective antimalarial vaccine. Curr Med Chem 18, 4470-4502.

Dame, J.B., Williams, J.L., McCutchan, T.F., Weber, J.L., Wirtz, R.A., Hockmeyer, W.T., Maloy, W.L., Haynes, J.D., Schneider, I., Roberts, D., et al. (1984). Structure of the gene encoding the immunodominant surface antigen on the sporozoite of the human malaria parasite Plasmodium falciparum. Science 225, 593-599.

Daubersies, P., Thomas, A.W., Millet, P., Brahimi, K., Langermans, J.A., Ollomo, B., BenMohamed, L., Slierendregt, B., Eling, W., Van Belkum, A., et al. (2000). Protection against Plasmodium falciparum malaria in chimpanzees by immunization with the conserved preerythrocytic liver-stage antigen 3. Nat Med 6, 1258-1263.

De Colibus, L., Sonnen, A.F., Morris, K.J., Siebert, C.A., Abrusci, P., Plitzko, J., Hodnik, V., Leippe, M., Volpi, E., Anderluh, G., et al. (2012). Structures of lysenin reveal a shared evolutionary origin for pore-forming proteins and its mode of sphingomyelin recognition. Structure 20, 1498-1507.

DeSimone, T.M., Jennings, C.V., Bei, A.K., Comeaux, C., Coleman, B.I., Refour, P., Triglia, T., Stubbs, J., Cowman, A.F., and Duraisingh, M.T. (2009). Cooperativity between Plasmodium falciparum adhesive proteins for invasion into erythrocytes. Mol Microbiol 72, 578-589.

Dluzewski, A.R., Ling, I.T., Hopkins, J.M., Grainger, M., Margos, G., Mitchell, G.H., Holder, A.A., and Bannister, L.H. (2008). Formation of the food vacuole in Plasmodium falciparum: a potential role for the $19 \mathrm{kDa}$ fragment of merozoite surface protein 1 (MSP1(19)). PLoS One 3, e3085.

Egan, E.S., Jiang, R.H., Moechtar, M.A., Barteneva, N.S., Weekes, M.P., Nobre, L.V., Gygi, S.P., Paulo, J.A., Frantzreb, C., Tani, Y., et al. (2015). Malaria. A forward genetic screen identifies erythrocyte CD55 as essential for Plasmodium falciparum invasion. Science 348, 711-714.

Ejigiri, I., Ragheb, D.R., Pino, P., Coppi, A., Bennett, B.L., Soldati-Favre, D., and Sinnis, P. (2012). Shedding of TRAP by a rhomboid protease from the malaria sporozoite surface is essential for gliding motility and sporozoite infectivity. PLoS Pathog 8, e1002725.

Engelmann, S., Silvie, O., and Matuschewski, K. (2009). Disruption of Plasmodium sporozoite transmission by depletion of sporozoite invasion-associated protein 1. Eukaryot Cell 8, 640-648.

Espinosa, D.A., Gutierrez, G.M., Rojas-Lopez, M., Noe, A.R., Shi, L., Tse, S.W., Sinnis, P., and Zavala, F. (2015). Proteolytic Cleavage of the $P$. falciparum Circumsporozoite Protein is a Target of Protective Antibodies. J Infect Dis First published online: March 11, 2015. 
Ferguson, D.J., Balaban, A.E., Patzewitz, E.M., Wall, R.J., Hopp, C.S., Poulin, B., Mohmmed, A., Malhotra, P., Coppi, A., Sinnis, P., et al. (2014). The repeat region of the circumsporozoite protein is critical for sporozoite formation and maturation in Plasmodium. PLoS One 9, e113923.

Fidock, D.A., Bottius, E., Brahimi, K., Moelans, II, Aikawa, M., Konings, R.N., Certa, U., Olafsson, P., Kaidoh, T., Asavanich, A., et al. (1994a). Cloning and characterization of a novel Plasmodium falciparum sporozoite surface antigen, STARP. Mol Biochem Parasitol 64, 219-232.

Fidock, D.A., Gras-Masse, H., Lepers, J.P., Brahimi, K., Benmohamed, L., Mellouk, S., Guerin-Marchand, C., Londono, A., Raharimalala, L., Meis, J.F., et al. (1994b). Plasmodium falciparum liver stage antigen-1 is well conserved and contains potent $B$ and $T$ cell determinants. J Immunol 153, 190-204.

Fidock, D.A., Pasquetto, V., Gras, H., Badell, E., Eling, W., Ballou, W.R., Belghiti, J., Tartar, A., and Druilhe, P. (1997). Plasmodium falciparum sporozoite invasion is inhibited by naturally acquired or experimentally induced polyclonal antibodies to the STARP antigen. Eur $\mathrm{J}$ Immunol 27, 2502-2513.

Frevert, U., Sinnis, P., Cerami, C., Shreffler, W., Takacs, B., and Nussenzweig, V. (1993). Malaria circumsporozoite protein binds to heparan sulfate proteoglycans associated with the surface membrane of hepatocytes. J Exp Med 177, 1287-1298.

Gao, X., Gunalan, K., Yap, S.S., and Preiser, P.R. (2013). Triggers of key calcium signals during erythrocyte invasion by Plasmodium falciparum. Nat Commun 4, 2862.

Gao, X., Yeo, K.P., Aw, S.S., Kuss, C., Iyer, J.K., Genesan, S., Rajamanonmani, R., Lescar, J., Bozdech, Z., and Preiser, P.R. (2008). Antibodies targeting the PfRH1 binding domain inhibit invasion of Plasmodium falciparum merozoites. PLoS Pathog 4, e1000104.

Garcia, J., Curtidor, H., Obando-Martinez, A.Z., Vizcaino, C., Pinto, M., Martinez, N.L., Patarroyo, M.A., and Patarroyo, M.E. (2009a). Synthetic peptides from conserved regions of the Plasmodium falciparum early transcribed membrane and ring exported proteins bind specifically to red blood cell proteins. Vaccine 27 , 6877-6886.

Garcia, J., Curtidor, H., Pinzon, C.G., Patarroyo, M.A., Vanegas, M., Forero, M., and Patarroyo, M.E. (2010). Well-defined regions of the Plasmodium falciparum reticulocyte binding protein homologue 4 mediate interaction with red blood cell membrane. J Med Chem 53, 811-821.

Garcia, J., Curtidor, H., Pinzon, C.G., Vanegas, M., Moreno, A., and Patarroyo, M.E. (2009b). Identification of conserved erythrocyte binding regions in members of the Plasmodium falciparum Cys6 lipid raft-associated protein family. Vaccine 27, 3953-3962.

Garcia, J.E., Puentes, A., Curtidor, H., Vera, R., Rodriguez, L., Valbuena, J., Lopez, R., Ocampo, M., Cortes, J., Vanegas, M., et al. (2005). Peptides from the Plasmodium falciparum STEVOR putative protein bind with high affinity to normal human red blood cells. Peptides 26, 1133-1143.
Garcia, J.E., Puentes, A., and Patarroyo, M.E. (2006). Developmental biology of sporozoite-host interactions in Plasmodium falciparum malaria: implications for vaccine design. Clin Microbiol Rev 19, 686-707.

Garcia, Y., Puentes, A., Curtidor, H., Cifuentes, G., Reyes, C., Barreto, J., Moreno, A., and Patarroyo, M.E. (2007). Identifying merozoite surface protein 4 and merozoite surface protein 7 Plasmodium falciparum protein family members specifically binding to human erythrocytes suggests a new malarial parasite-redundant survival mechanism. J Med Chem 50, 5665-5675.

Gaur, D., Singh, S., Singh, S., Jiang, L., Diouf, A., and Miller, L.H. (2007). Recombinant Plasmodium falciparum reticulocyte homology protein 4 binds to erythrocytes and blocks invasion. Proc Natl Acad Sci U S A 104, 17789-17794.

Ghai, M., Dutta, S., Hall, T., Freilich, D., and Ockenhouse, C.F. (2002). Identification, expression, and functional characterization of MAEBL, a sporozoite and asexual blood stage chimeric erythrocyte-binding protein of Plasmodium falciparum. Mol Biochem Parasitol 123, 35-45.

Giddings, K.S., Zhao, J., Sims, P.J., and Tweten, R.K. (2004). Human CD59 is a receptor for the cholesteroldependent cytolysin intermedilysin. Nat Struct Mol Biol 11, 1173-1178.

Gilson, P.R., Nebl, T., Vukcevic, D., Moritz, R.L., Sargeant, T., Speed, T.P., Schofield, L., and Crabb, B.S. (2006). Identification and stoichiometry of glycosylphosphatidylinositol-anchored membrane proteins of the human malaria parasite Plasmodium falciparum. Mol Cell Proteomics 5, 1286-1299.

Giovannini, D., Spath, S., Lacroix, C., Perazzi, A., Bargieri, D., Lagal, V., Lebugle, C., Combe, A., Thiberge, S., Baldacci, P., et al. (2011). Independent roles of apical membrane antigen 1 and rhoptry neck proteins during host cell invasion by apicomplexa. Cell Host Microbe 10, 591-602.

Goel, S., Palmkvist, M., Moll, K., Joannin, N., Lara, P., Akhouri, R.R., Moradi, N., Ojemalm, K., Westman, M., Angeletti, D., et al. (2015). RIFINs are adhesins implicated in severe Plasmodium falciparum malaria. Nat Med 21, 314-317.

Goldberg, D.E. (2012). Plasmodium protein export at higher PEXEL resolution. Cell Host Microbe 12, 609-610.

Gruring, C., Heiber, A., Kruse, F., Flemming, S., Franci, G., Colombo, S.F., Fasana, E., Schoeler, H., Borgese, N., Stunnenberg, H.G., et al. (2012). Uncovering common principles in protein export of malaria parasites. Cell Host Microbe 12, 717-729.

Gunalan, K., Gao, X., Liew, K.J., and Preiser, P.R. (2011). Differences in erythrocyte receptor specificity of different parts of the Plasmodium falciparum reticulocyte binding protein homologue 2a. Infect Immun 79, 3421-3430.

Gupta, A., Thiruvengadam, G., and Desai, S.A. (2015). The conserved clag multigene family of malaria parasites: essential roles in host-pathogen interaction. Drug Resist Updat 18, 47-54.

Hadders, M.A., Beringer, D.X., and Gros, P. (2007). Structure of C8alpha-MACPF reveals mechanism of membrane attack in complement immune defense. Science 317, 1552-1554. 
Hamaoka, B.Y., and Ghosh, P. (2014). Structure of the essential Plasmodium host cell traversal protein SPECT1. PLoS One 9, e114685.

Hawthorne, P.L., Trenholme, K.R., Skinner-Adams, T.S., Spielmann, T., Fischer, K., Dixon, M.W., Ortega, M.R., Anderson, K.L., Kemp, D.J., and Gardiner, D.L. (2004). A novel Plasmodium falciparum ring stage protein, REX, is located in Maurer's clefts. Mol Biochem Parasitol 136, 181-189.

Hegge, S., Kudryashev, M., Barniol, L., and Frischknecht, F. (2010). Key factors regulating Plasmodium berghei sporozoite survival and transformation revealed by an automated visual assay. FASEB J 24, 5003-5012.

Hodder, A.N., Crewther, P.E., Matthew, M.L., Reid, G.E., Moritz, R.L., Simpson, R.J., and Anders, R.F. (1996). The disulfide bond structure of Plasmodium apical membrane antigen-1. J Biol Chem 271, 29446-29452.

Hodder, A.N., Malby, R.L., Clarke, O.B., Fairlie, W.D., Colman, P.M., Crabb, B.S., and Smith, B.J. (2009). Structural insights into the protease-like antigen Plasmodium falciparum SERA5 and its noncanonical active-site serine. J Mol Biol 392, 154-165.

Howell, S.A., Withers-Martinez, C., Kocken, C.H., Thomas, A.W., and Blackman, M.J. (2001). Proteolytic processing and primary structure of Plasmodium falciparum apical membrane antigen-1. J Biol Chem 276, 31311-31320.

Ishino, T., Yano, K., Chinzei, Y., and Yuda, M. (2004). Cellpassage activity is required for the malarial parasite to cross the liver sinusoidal cell layer. PLoS Biol 2, E4.

Kaiser, K., Matuschewski, K., Camargo, N., Ross, J., and Kappe, S.H. (2004). Differential transcriptome profiling identifies Plasmodium genes encoding pre-erythrocytic stage-specific proteins. Mol Microbiol 51, 1221-1232.

Kanodia, S., Kumar, G., Rizzi, L., Pedretti, A., Hodder, A.N., Romeo, S., and Malhotra, P. (2014). Synthetic peptides derived from the C-terminal $6 \mathrm{kDa}$ region of Plasmodium falciparum SERA5 inhibit the enzyme activity and malaria parasite development. Biochim Biophys Acta 1840, 2765-2775.

Kappe, S.H., Kaiser, K., and Matuschewski, K. (2003). The Plasmodium sporozoite journey: a rite of passage. Trends Parasitol 19, 135-143.

Kariu, T., Ishino, T., Yano, K., Chinzei, Y., and Yuda, M. (2006). CelTOS, a novel malarial protein that mediates transmission to mosquito and vertebrate hosts. Mol Microbiol 59, 1369-1379.

Kauth, C.W., Woehlbier, U., Kern, M., Mekonnen, Z., Lutz, R., Mucke, N., Langowski, J., and Bujard, H. (2006). Interactions between merozoite surface proteins 1, 6, and 7 of the malaria parasite Plasmodium falciparum. J Biol Chem 281, 31517-31527.

Kudryashev, M., Lepper, S., Stanway, R., Bohn, S., Baumeister, W., Cyrklaff, M., and Frischknecht, F. (2010). Positioning of large organelles by a membraneassociated cytoskeleton in Plasmodium sporozoites. Cell Microbiol 12, 362-371.

Kurtis, J.D., Lanar, D.E., Opollo, M., and Duffy, P.E. (1999). Interleukin-10 responses to liver-stage antigen 1 predict human resistance to Plasmodium falciparum. Infect Immun 67, 3424-3429.

Labaied, M., Camargo, N., and Kappe, S.H. (2007). Depletion of the Plasmodium berghei thrombospondin- related sporozoite protein reveals a role in host cell entry by sporozoites. Mol Biochem Parasitol 153, 158-166.

LaCount, D.J., Vignali, M., Chettier, R., Phansalkar, A., Bell, R., Hesselberth, J.R., Schoenfeld, L.W., Ota, I., Sahasrabudhe, S., Kurschner, C., et al. (2005). A protein interaction network of the malaria parasite Plasmodium falciparum. Nature 438, 103-107.

Lanzillotti, R., and Coetzer, T.L. (2006). The $10 \mathrm{kDa}$ domain of human erythrocyte protein 4.1 binds the Plasmodium falciparum EBA-181 protein. Malar J 5, 100.

Lasonder, E., Janse, C.J., van Gemert, G.J., Mair, G.R., Vermunt, A.M., Douradinha, B.G., van Noort, V., Huynen, M.A., Luty, A.J., Kroeze, H., et al. (2008). Proteomic profiling of Plasmodium sporozoite maturation identifies new proteins essential for parasite development and infectivity. PLoS Pathog 4, e1000195.

Law, R.H., Lukoyanova, N., Voskoboinik, I., CaradocDavies, T.T., Baran, K., Dunstone, M.A., D'Angelo, M.E., Orlova, E.V., Coulibaly, F., Verschoor, S., et al. (2010). The structural basis for membrane binding and pore formation by lymphocyte perforin. Nature 468, 447-451.

Leykauf, K., Treeck, M., Gilson, P.R., Nebl, T., Braulke, T., Cowman, A.F., Gilberger, T.W., and Crabb, B.S. (2010). Protein kinase a dependent phosphorylation of apical membrane antigen 1 plays an important role in erythrocyte invasion by the malaria parasite. PLoS Pathog 6, e1000941.

Li, X., Chen, H., Oo, T.H., Daly, T.M., Bergman, L.W., Liu, S.C., Chishti, A.H., and Oh, S.S. (2004). A co-ligand complex anchors Plasmodium falciparum merozoites to the erythrocyte invasion receptor band 3. J Biol Chem 279, 5765-5771.

Li, X., Marinkovic, M., Russo, C., McKnight, C.J., Coetzer, T.L., and Chishti, A.H. (2012). Identification of a specific region of Plasmodium falciparum EBL-1 that binds to host receptor glycophorin $B$ and inhibits merozoite invasion in human red blood cells. Mol Biochem Parasitol 183, 23-31.

Lin, D.H., Malpede, B.M., Batchelor, J.D., and Tolia, N.H. (2012). Crystal and solution structures of Plasmodium falciparum erythrocyte-binding antigen 140 reveal determinants of receptor specificity during erythrocyte invasion. J Biol Chem 287, 36830-36836.

Lindner, S.E., Swearingen, K.E., Harupa, A., Vaughan, A.M., Sinnis, P., Moritz, R.L., and Kappe, S.H. (2013). Total and putative surface proteomics of malaria parasite salivary gland sporozoites. Mol Cell Proteomics 12, 1127-1143.

Lopaticki, S., Maier, A.G., Thompson, J., Wilson, D.W., Tham, W.H., Triglia, T., Gout, A., Speed, T.P., Beeson, J.G., Healer, J., et al. (2011). Reticulocyte and erythrocyte binding-like proteins function cooperatively in invasion of human erythrocytes by malaria parasites. Infect Immun 79, 1107-1117.

Lopez-Estrano, C., Bhattacharjee, S., Harrison, T., and Haldar, K. (2003). Cooperative domains define a unique host cell-targeting signal in Plasmodium falciparuminfected erythrocytes. Proc Natl Acad Sci U S A 100, 12402-12407.

Lozano, J.M., Guerrero, Y.A., Alba, M.P., Lesmes, L.P., Escobar, J.O., and Patarroyo, M.E. (2013). Redefining an epitope of a malaria vaccine candidate, with antibodies 
against the N-terminal MSA-2 antigen of Plasmodium harboring non-natural peptide bonds. Amino Acids 45, 913-935.

MacRaild, C.A., Pedersen, M.O., Anders, R.F., and Norton, R.S. (2012). Lipid interactions of the malaria antigen merozoite surface protein 2. Biochim Biophys Acta 1818, 2572-2578.

Malpede, B.M., Lin, D.H., and Tolia, N.H. (2013). Molecular basis for sialic acid-dependent receptor recognition by the Plasmodium falciparum invasion protein erythrocytebinding antigen-140/BAEBL. J Biol Chem 288, 12406-12415.

Mayer, D.C., Cofie, J., Jiang, L., Hartl, D.L., Tracy, E., Kabat, J., Mendoza, L.H., and Miller, L.H. (2009). Glycophorin B is the erythrocyte receptor of Plasmodium falciparum erythrocyte-binding ligand, EBL-1. Proc Natl Acad Sci U S A 106, 5348-5352.

Mitchell, G.H., Thomas, A.W., Margos, G., Dluzewski, A.R., and Bannister, L.H. (2004). Apical membrane antigen 1, a major malaria vaccine candidate, mediates the close attachment of invasive merozoites to host red blood cells. Infect Immun 72, 154-158.

Moreira, C.K., Templeton, T.J., Lavazec, C., Hayward, R.E., Hobbs, C.V., Kroeze, H., Janse, C.J., Waters, A.P., Sinnis, P., and Coppi, A. (2008). The Plasmodium TRAP/ MIC2 family member, TRAP-Like Protein (TLP), is involved in tissue traversal by sporozoites. Cell Microbiol 10, 1505-1516.

Mota, M.M., Hafalla, J.C., and Rodriguez, A. (2002). Migration through host cells activates Plasmodium sporozoites for infection. Nat Med 8, 1318-1322.

Munter, S., Sabass, B., Selhuber-Unkel, C., Kudryashev, M., Hegge, S., Engel, U., Spatz, J.P., Matuschewski, K., Schwarz, U.S., and Frischknecht, F. (2009). Plasmodium sporozoite motility is modulated by the turnover of discrete adhesion sites. Cell Host Microbe 6, 551-562.

Nguitragool, W., Rayavara, K., and Desai, S.A. (2014). Proteolysis at a specific extracellular residue implicates integral membrane CLAG3 in malaria parasite nutrient channels. PLoS One 9, e93759.

Nguyen, T.V., Fujioka, H., Kang, A.S., Rogers, W.O., Fidock, D.A., and James, A.A. (2001). Stage-dependent localization of a novel gene product of the malaria parasite, Plasmodium falciparum. J Biol Chem 276, 26724-26731.

Niang, M., Bei, A.K., Madnani, K.G., Pelly, S., Dankwa, S., Kanjee, U., Gunalan, K., Amaladoss, A., Yeo, K.P., Bob, N.S., et al. (2014). STEVOR is a Plasmodium falciparum erythrocyte binding protein that mediates merozoite invasion and rosetting. Cell Host Microbe 16, 81-93.

Niang, M., Yan Yam, X., and Preiser, P.R. (2009). The Plasmodium falciparum STEVOR multigene family mediates antigenic variation of the infected erythrocyte. PLoS Pathog 5, e1000307.

O'Brien, D.P., Romero-Gallo, J., Schneider, B.G., Chaturvedi, R., Delgado, A., Harris, E.J., Krishna, U., Ogden, S.R., Israel, D.A., Wilson, K.T., et al. (2008). Regulation of the Helicobacter pylori cellular receptor decay-accelerating factor. J Biol Chem 283, 23922-23930.

Osier, F.H., Mackinnon, M.J., Crosnier, C., Fegan, G., Kamuyu, G., Wanaguru, M., Ogada, E., McDade, B.,
Rayner, J.C., Wright, G.J., et al. (2014). New antigens for a multicomponent blood-stage malaria vaccine. Sci Transl Med 6, 247 ra102.

Pachebat, J.A., Kadekoppala, M., Grainger, M., Dluzewski, A.R., Gunaratne, R.S., Scott-Finnigan, T.J., Ogun, S.A., Ling, I.T., Bannister, L.H., Taylor, H.M., et al. (2007). Extensive proteolytic processing of the malaria parasite merozoite surface protein 7 during biosynthesis and parasite release from erythrocytes. Mol Biochem Parasitol 151, 59-69.

Park, H.J., Guariento, M., Maciejewski, M., Hauhart, R., Tham, W.H., Cowman, A.F., Schmidt, C.Q., Mertens, H.D., Liszewski, M.K., Hourcade, D.E., et al. (2014). Using mutagenesis and structural biology to map the binding site for the Plasmodium falciparum merozoite protein PfRh4 on the human immune adherence receptor. J Biol Chem 289, 450-463.

Patarroyo, M.E., Alba, M.P., Curtidor, H., Vanegas, M., Almonacid, H., and Patarroyo, M.A. (2014). Using the PfEMP1 head structure binding motif to deal a blow at severe malaria. PLoS One 9, e88420.

Patarroyo, M.E., Alba, M.P., Reyes, C., Rojas-Luna, R., and Patarroyo, M.A. (2015a). The Malaria Parasite's Achilles' Heel: Functionally-relevant Invasion Structures. Curr Issues Mol Biol 18, 11-20.

Patarroyo, M.E., Amador, R., Clavijo, P., Moreno, A., Guzman, F., Romero, P., Tascon, R., Franco, A., Murillo, L.A., Ponton, G., et al. (1988). A synthetic vaccine protects humans against challenge with asexual blood stages of Plasmodium falciparum malaria. Nature 332, 158-161.

Patarroyo, M.E., Bermudez, A., Alba, M.P., Vanegas, M., Moreno-Vranich, A., Poloche, L.A., and Patarroyo, M.A. (2015b). IMPIPS: the immune protection-inducing protein structure concept in the search for steric-electron and topochemical principles for complete fully-protective chemically synthesised vaccine development. PLoS One 10, e0123249.

Patarroyo, M.E., Bermudez, A., and Patarroyo, M.A. (2011). Structural and immunological principles leading to chemically synthesized, multiantigenic, multistage, minimal subunit-based vaccine development. Chem Rev 111, 3459-3507.

Patarroyo, M.E., Cifuentes, G., Salazar, L.M., Espejo, F., Alba, M.P., and Bermudez, A. (2005). Based on HLA-DR beta1* allele binding specificities, striking differences in distance and TCR Contacting Residue Orientation can be observed in modified protection-inducing malarial synthetic peptides. Curr Med Chem 12, 2849-2865.

Patarroyo, M.E., and Patarroyo, M.A. (2008). Emerging rules for subunit-based, multiantigenic, multistage chemically synthesized vaccines. Acc Chem Res 41, 377-386.

Patarroyo, M.E., Romero, P., Torres, M.L., Clavijo, P., Moreno, A., Martinez, A., Rodriguez, R., Guzman, F., and Cabezas, E. (1987). Induction of protective immunity against experimental infection with malaria using synthetic peptides. Nature 328, 629-632.

Paul, A.S., Egan, E.S., and Duraisingh, M.T. (2015). Hostparasite interactions that guide red blood cell invasion by malaria parasites. Curr Opin Hematol 22, 220-226. 
Persson, K.E., McCallum, F.J., Reiling, L., Lister, N.A., Stubbs, J., Cowman, A.F., Marsh, K., and Beeson, J.G. (2008). Variation in use of erythrocyte invasion pathways by Plasmodium falciparum mediates evasion of human inhibitory antibodies. J Clin Invest 118, 342-351.

Pihlajamaa, T., Kajander, T., Knuuti, J., Horkka, K., Sharma, A., and Permi, P. (2013). Structure of Plasmodium falciparum TRAP (thrombospondin-related anonymous protein) $A$ domain highlights distinct features in apicomplexan von Willebrand factor A homologues. Biochem J 450, 469-476.

Pinzon, C.G., Curtidor, H., Bermudez, A., Forero, M., Vanegas, M., Rodriguez, J., and Patarroyo, M.E. (2008a). Studies of Plasmodium falciparum rhoptryassociated membrane antigen (RAMA) protein peptides specifically binding to human RBC. Vaccine 26 , 853-862.

Pinzon, C.G., Curtidor, H., Garcia, J., Vanegas, M., Vizcaino, C., Patarroyo, M.A., and Patarroyo, M.E. (2010). Sequences of the Plasmodium falciparum cytoadherence-linked asexual protein 9 implicated in malaria parasite invasion to erythrocytes. Vaccine 28 , 2653-2663.

Pinzon, C.G., Curtidor, H., Reyes, C., Mendez, D., and Patarroyo, M.E. (2008b). Identification of Plasmodium falciparum RhopH3 protein peptides that specifically bind to erythrocytes and inhibit merozoite invasion. Protein Sci 17, 1719-1730.

Polekhina, G., Giddings, K.S., Tweten, R.K., and Parker, M.W. (2005). Insights into the action of the superfamily of cholesterol-dependent cytolysins from studies of intermedilysin. Proc Natl Acad Sci U S A 102, 600-605.

Puentes, A., Garcia, J., Ocampo, M., Rodriguez, L., Vera, R., Curtidor, H., Lopez, R., Suarez, J., Valbuena, J., Vanegas, M., et al. (2003). P. falciparum: merozoite surface protein-8 peptides bind specifically to human erythrocytes. Peptides 24, 1015-1023.

Ranjan, R., Chugh, M., Kumar, S., Singh, S., Kanodia, S., Hossain, M.J., Korde, R., Grover, A., Dhawan, S., Chauhan, V.S., et al. (2011). Proteome analysis reveals a large merozoite surface protein-1 associated complex on the Plasmodium falciparum merozoite surface. J Proteome Res 10, 680-691.

Rathore, D., Sacci, J.B., de la Vega, P., and McCutchan, T.F. (2002). Binding and invasion of liver cells by Plasmodium falciparum sporozoites. Essential involvement of the amino terminus of circumsporozoite protein. J Biol Chem 277, 7092-7098.

Reddy, K.S., Amlabu, E., Pandey, A.K., Mitra, P., Chauhan, V.S., and Gaur, D. (2015). Multiprotein complex between the GPI-anchored CyRPA with PfRH5 and PfRipr is crucial for Plasmodium falciparum erythrocyte invasion. Proc Natl Acad Sci U S A 112, 1179-1184.

Riglar, D.T., Richard, D., Wilson, D.W., Boyle, M.J., Dekiwadia, C., Turnbull, L., Angrisano, F., Marapana, D.S., Rogers, K.L., Whitchurch, C.B., et al. (2011). Super-resolution dissection of coordinated events during malaria parasite invasion of the human erythrocyte. Cell Host Microbe 9, 9-20.

Rodriguez, L.E., Curtidor, H., Urquiza, M., Cifuentes, G., Reyes, C., and Patarroyo, M.E. (2008). Intimate molecular interactions of $\mathrm{P}$. falciparum merozoite proteins involved in invasion of red blood cells and their implications for vaccine design. Chem Rev 108, 3656-3705.

Rogers, W.O., Malik, A., Mellouk, S., Nakamura, K., Rogers, M.D., Szarfman, A., Gordon, D.M., Nussler, A.K., Aikawa, M., and Hoffman, S.L. (1992). Characterization of Plasmodium falciparum sporozoite surface protein 2. Proc Natl Acad Sci U S A 89, 9176-9180.

Rosado, C.J., Kondos, S., Bull, T.E., Kuiper, M.J., Law, R.H., Buckle, A.M., Voskoboinik, I., Bird, P.I., Trapani, J.A., Whisstock, J.C., et al. (2008). The MACPF/CDC family of pore-forming toxins. Cell Microbiol 10, 1765-1774.

Rts, S.C.T.P. (2015). Efficacy and safety of RTS,S/AS01 malaria vaccine with or without a booster dose in infants and children in Africa: final results of a phase 3, individually randomised, controlled trial. Lancet Published Online: 23 April 2015.

Saenz, F.E., Balu, B., Smith, J., Mendonca, S.R., and Adams, J.H. (2008). The transmembrane isoform of Plasmodium falciparum MAEBL is essential for the invasion of Anopheles salivary glands. PLoS One 3, e2287.

Sakura, T., Yahata, K., and Kaneko, O. (2013). The upstream sequence segment of the C-terminal cysteinerich domain is required for microneme trafficking of Plasmodium falciparum erythrocyte binding antigen 175. Parasitol Int 62, 157-164.

Salanti, A., Dahlback, M., Turner, L., Nielsen, M.A., Barfod, L., Magistrado, P., Jensen, A.T., Lavstsen, T., Ofori, M.F., Marsh, K., et al. (2004). Evidence for the involvement of VAR2CSA in pregnancy-associated malaria. J Exp Med 200, 1197-1203.

Salinas, N.D., Paing, M.M., and Tolia, N.H. (2014). Critical glycosylated residues in exon three of erythrocyte glycophorin a engage Plasmodium falciparum EBA-175 and define receptor specificity. MBio 5, e01606-01614.

Salinas, N.D., and Tolia, N.H. (2014). A quantitative assay for binding and inhibition of Plasmodium falciparum Erythrocyte Binding Antigen 175 reveals high affinity binding depends on both DBL domains. Protein Expr Purif 95, 188-194.

Sanders, P.R., Gilson, P.R., Cantin, G.T., Greenbaum, D.C., Nebl, T., Carucci, D.J., McConville, M.J., Schofield, L., Hodder, A.N., Yates, J.R., 3rd, et al. (2005). Distinct protein classes including novel merozoite surface antigens in Raft-like membranes of Plasmodium falciparum. J Biol Chem 280, 40169-40176.

Sanders, P.R., Kats, L.M., Drew, D.R., O'Donnell, R.A., O'Neill, M., Maier, A.G., Coppel, R.L., and Crabb, B.S. (2006). A set of glycosylphosphatidyl inositol-anchored membrane proteins of Plasmodium falciparum is refractory to genetic deletion. Infect Immun 74, 4330-4338.

Sanyal, S., Egee, S., Bouyer, G., Perrot, S., Safeukui, I., Bischoff, E., Buffet, P., Deitsch, K.W., MercereauPuijalon, O., David, P.H., et al. (2012). Plasmodium falciparum STEVOR proteins impact erythrocyte mechanical properties. Blood 119, e1-8.

Schulze, J., Kwiatkowski, M., Borner, J., Schluter, H., Bruchhaus, I., Burmester, T., Spielmann, T., and Pick, C. (2015). The Plasmodium falciparum exportome contains non-canonical PEXEL/HT proteins. Mol Microbiol. 
Schussek, S., Trieu, A., Apte, S.H., Sidney, J., Sette, A., and Doolan, D.L. (2013). Immunization with apical membrane antigen 1 confers sterile infection-blocking immunity against Plasmodium sporozoite challenge in a rodent model. Infect Immun 81, 3586-3599.

Siau, A., Silvie, O., Franetich, J.F., Yalaoui, S., Marinach, C., Hannoun, L., van Gemert, G.J., Luty, A.J., Bischoff, E., David, P.H., et al. (2008). Temperature shift and host cell contact up-regulate sporozoite expression of Plasmodium falciparum genes involved in hepatocyte infection. PLoS Pathog 4, e1000121.

Sim, B.K., Orlandi, P.A., Haynes, J.D., Klotz, F.W., Carter, J.M., Camus, D., Zegans, M.E., and Chulay, J.D. (1990). Primary structure of the $175 \mathrm{~K}$ Plasmodium falciparum erythrocyte binding antigen and identification of a peptide which elicits antibodies that inhibit malaria merozoite invasion. J Cell Biol 111, 1877-1884.

Singh, A.P., Buscaglia, C.A., Wang, Q., Levay, A., Nussenzweig, D.R., Walker, J.R., Winzeler, E.A., Fujii, H., Fontoura, B.M., and Nussenzweig, V. (2007). Plasmodium circumsporozoite protein promotes the development of the liver stages of the parasite. Cell 131, 492-504.

Singh, S., Alam, M.M., Pal-Bhowmick, I., Brzostowski, J.A., and Chitnis, C.E. (2010). Distinct external signals trigger sequential release of apical organelles during erythrocyte invasion by malaria parasites. PLoS Pathog 6, e1000746.

Smith, J.D., Rowe, J.A., Higgins, M.K., and Lavstsen, T. (2013). Malaria's deadly grip: cytoadhesion of Plasmodium falciparum-infected erythrocytes. Cell Microbiol 15, 1976-1983.

Song, G., Koksal, A.C., Lu, C., and Springer, T.A. (2012). Shape change in the receptor for gliding motility in Plasmodium sporozoites. Proc Natl Acad Sci U S A 109, 21420-21425.

Spielmann, T., Hawthorne, P.L., Dixon, M.W., Hannemann, M., Klotz, K., Kemp, D.J., Klonis, N., Tilley, L., Trenholme, K.R., and Gardiner, D.L. (2006). A cluster of ring stage-specific genes linked to a locus implicated in cytoadherence in Plasmodium falciparum codes for PEXEL-negative and PEXEL-positive proteins exported into the host cell. Mol Biol Cell 17, 3613-3624.

Spillman, N.J., Beck, J.R., and Goldberg, D.E. (2015). Protein export into malaria parasite-infected erythrocytes: mechanisms and functional consequences. Annu Rev Biochem 84, 813-841.

Stallmach, R., Kavishwar, M., Withers-Martinez, C., Hackett, F., Collins, C.R., Howell, S.A., Yeoh, S., Knuepfer, E., Atid, A.J., Holder, A.A., et al. (2015). Plasmodium falciparum SERA5 plays a non-enzymatic role in the malarial asexual blood-stage lifecycle. Mol Microbiol 96, 368-387.

Stubbs, J., Simpson, K.M., Triglia, T., Plouffe, D., Tonkin, C.J., Duraisingh, M.T., Maier, A.G., Winzeler, E.A., and Cowman, A.F. (2005). Molecular mechanism for switching of $P$. falciparum invasion pathways into human erythrocytes. Science 309, 1384-1387.

Sultan, A.A., Thathy, V., Frevert, U., Robson, K.J., Crisanti, A., Nussenzweig, V., Nussenzweig, R.S., and Menard, R. (1997). TRAP is necessary for gliding motility and infectivity of plasmodium sporozoites. Cell 90, 511-522.
Thompson, J., Cooke, R.E., Moore, S., Anderson, L.F., Janse, C.J., and Waters, A.P. (2004). PTRAMP; a conserved Plasmodium thrombospondin-related apical merozoite protein. Mol Biochem Parasitol 134, 225-232.

Tolia, N.H., Enemark, E.J., Sim, B.K., and Joshua-Tor, L. (2005). Structural basis for the EBA-175 erythrocyte invasion pathway of the malaria parasite Plasmodium falciparum. Cell 122, 183-193.

Tonkin, M.L., Arredondo, S.A., Loveless, B.C., Serpa, J.J., Makepeace, K.A., Sundar, N., Petrotchenko, E.V., Miller, L.H., Grigg, M.E., and Boulanger, M.J. (2013). Structural and biochemical characterization of Plasmodium falciparum 12 (Pf12) reveals a unique interdomain organization and the potential for an antiparallel arrangement with Pf41. J Biol Chem 288, 12805-12817.

Topolska, A.E., Lidgett, A., Truman, D., Fujioka, H., and Coppel, R.L. (2004). Characterization of a membraneassociated rhoptry protein of Plasmodium falciparum. J Biol Chem 279, 4648-4656.

Tossavainen, H., Pihlajamaa, T., Huttunen, T.K., Raulo, E., Rauvala, H., Permi, P., and Kilpelainen, I. (2006). The layered fold of the TSR domain of $P$. falciparum TRAP contains a heparin binding site. Protein Sci 15, 1760-1768.

Trenholme, K.R., Gardiner, D.L., Holt, D.C., Thomas, E.A., Cowman, A.F., and Kemp, D.J. (2000). clag9: A cytoadherence gene in Plasmodium falciparum essential for binding of parasitized erythrocytes to CD36. Proc Natl Acad Sci U S A 97, 4029-4033.

Triglia, T., Tham, W.H., Hodder, A., and Cowman, A.F. (2009). Reticulocyte binding protein homologues are key adhesins during erythrocyte invasion by Plasmodium falciparum. Cell Microbiol 11, 1671-1687.

Trucco, C., Fernandez-Reyes, D., Howell, S., Stafford, W.H., Scott-Finnigan, T.J., Grainger, M., Ogun, S.A., Taylor, W.R., and Holder, A.A. (2001). The merozoite surface protein 6 gene codes for a $36 \mathrm{kDa}$ protein associated with the Plasmodium falciparum merozoite surface protein-1 complex. Mol Biochem Parasitol 112, 91-101.

Tucker, R.P. (2004). The thrombospondin type 1 repeat superfamily. Int J Biochem Cell Biol 36, 969-974.

Urquiza, M., Rodriguez, L.E., Suarez, J.E., Guzman, F., Ocampo, M., Curtidor, H., Segura, C., Trujillo, E., and Patarroyo, M.E. (1996). Identification of Plasmodium falciparum MSP-1 peptides able to bind to human red blood cells. Parasite Immunol 18, 515-526.

Vaughan, A.M., Aly, A.S., and Kappe, S.H. (2008). Malaria parasite pre-erythrocytic stage infection: gliding and hiding. Cell Host Microbe 4, 209-218.

Vigan-Womas, I., Guillotte, M., Juillerat, A., Hessel, A., Raynal, B., England, P., Cohen, J.H., Bertrand, O., Peyrard, T., Bentley, G.A., et al. (2012). Structural basis for the $A B O$ blood-group dependence of Plasmodium falciparum rosetting. PLoS Pathog 8, e1002781.

Wanaguru, M., Crosnier, C., Johnson, S., Rayner, J.C., and Wright, G.J. (2013a). Biochemical analysis of the Plasmodium falciparum erythrocyte-binding antigen-175 (EBA175)-glycophorin-A interaction: implications for vaccine design. J Biol Chem 288, 32106-32117.

Wanaguru, M., Liu, W., Hahn, B.H., Rayner, J.C., and Wright, G.J. (2013b). RH5-Basigin interaction plays a 
major role in the host tropism of Plasmodium falciparum. Proc Natl Acad Sci U S A 110, 20735-20740.

Weiss, G.E., Gilson, P.R., Taechalertpaisarn, T., Tham, W.H., de Jong, N.W., Harvey, K.L., Fowkes, F.J., Barlow, P.N., Rayner, J.C., Wright, G.J., et al. (2015). Revealing the Sequence and Resulting Cellular Morphology of Receptor-Ligand Interactions during Plasmodium falciparum Invasion of Erythrocytes. PLoS Pathog 11, e1004670.

World Health Orgaanization (2014). World Malaria Report 2014. Geneva, 219.

Wright, K.E., Hjerrild, K.A., Bartlett, J., Douglas, A.D., Jin, J., Brown, R.E., Illingworth, J.J., Ashfield, R., Clemmensen, S.B., de Jongh, W.A., et al. (2014). Structure of malaria invasion protein $\mathrm{RH} 5$ with erythrocyte basigin and blocking antibodies. Nature 515, 427-430.

Wuchty, S. (2007). Rich-club phenomenon in the interactome of $\mathrm{P}$. falciparum--artifact or signature of a parasitic life style? PLoS One 2, e335.

Zhang, X., Perugini, M.A., Yao, S., Adda, C.G., Murphy, V.J., Low, A., Anders, R.F., and Norton, R.S. (2008). Solution conformation, backbone dynamics and lipid interactions of the intrinsically unstructured malaria surface protein MSP2. J Mol Biol 379, 105-121.

Zhang, Y., Jiang, N., Chang, Z., Wang, H., Lu, H., Wahlgren, M., and Chen, Q. (2014). The var3 genes of Plasmodium falciparum 3D7 strain are differentially expressed in infected erythrocytes. Parasite 21, 19. 


\section{Microbiology / Molecular Biology}

Caister Academic Press is a leading academic publisher of advanced texts in microbiology, molecular biology and medical research. Full details of all our publications at caister.com

- Cyanobacteria: Omics and Manipulation Edited by: DA Los (2017) www.caister.com/cyano3

- Brain-eating Amoebae: Biology and Pathogenesis of Naegleria fowleri

Author: R Siddiqui, IKM Ali, JR Cope, et al. (2016)

"explains the current knowledge and research" (ProtoView) www.caister.com/naegleria

- Foot and Mouth Disease Virus: Current Research and Emerging Trends

Edited by: F Sobrino, E Domingo (2017)

www.caister.com/fmdv

- Staphylococcus: Genetics and Physiology

Edited by: GA Somerville (2016)

www.caister.com/staph2

- Chloroplasts: Current Research and Future Trends Edited by: H Kirchhoff (2016)

www.caister.com/chloroplasts

- Microbial Biodegradation: From Omics to Function and Application

Edited by: J Długoński (2016)

www.caister.com/biodegradation

- Influenza: Current Research

Edited by: Q Wang, YJ Tao (2016)

www.caister.com/flu3

- MALDI-TOF Mass Spectrometry in Microbiology Edited by: M Kostrzewa, S Schubert (2016)

www.caister.com/malditof

- Aspergillus and Penicillium in the Post-genomic Era Edited by: RP Vries, IB Gelber, MR Andersen (2016)

"new and well-presented book" (IMA Fungus)

www.caister.com/aspergillus2

- The Bacteriocins: Current Knowledge and Future

Prospects

Edited by: RL Dorit, SM Roy, MA Riley (2016)

www.caister.com/bacteriocins

- Omics in Plant Disease Resistance

Edited by: V Bhadauria (2016)

"essential reading ... highly recommended" (Biotechnol. Agron.

Soc. Environ.)

www.caister.com/opdr

- Acidophiles: Life in Extremely Acidic Environments

Edited by: R Quatrini, DB Johnson (2016)

"Contributors from a wide range of biological and environmental sciences" (ProtoView)

www.caister.com/acidophiles
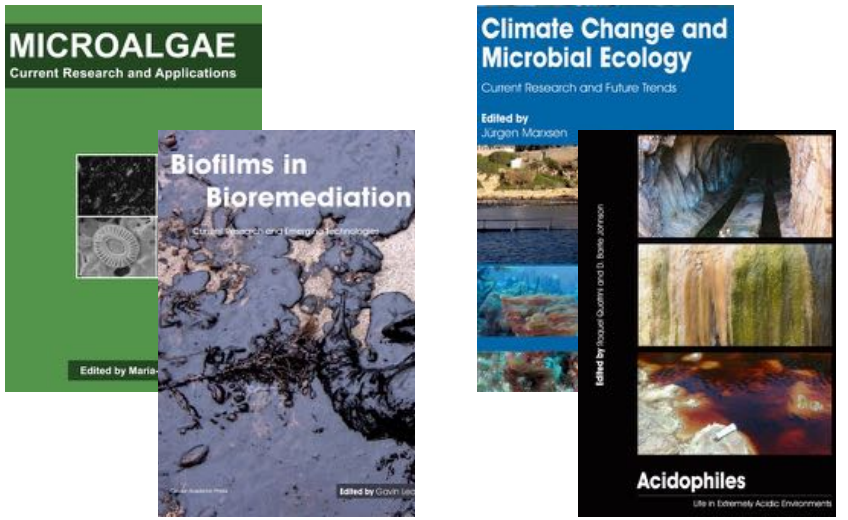
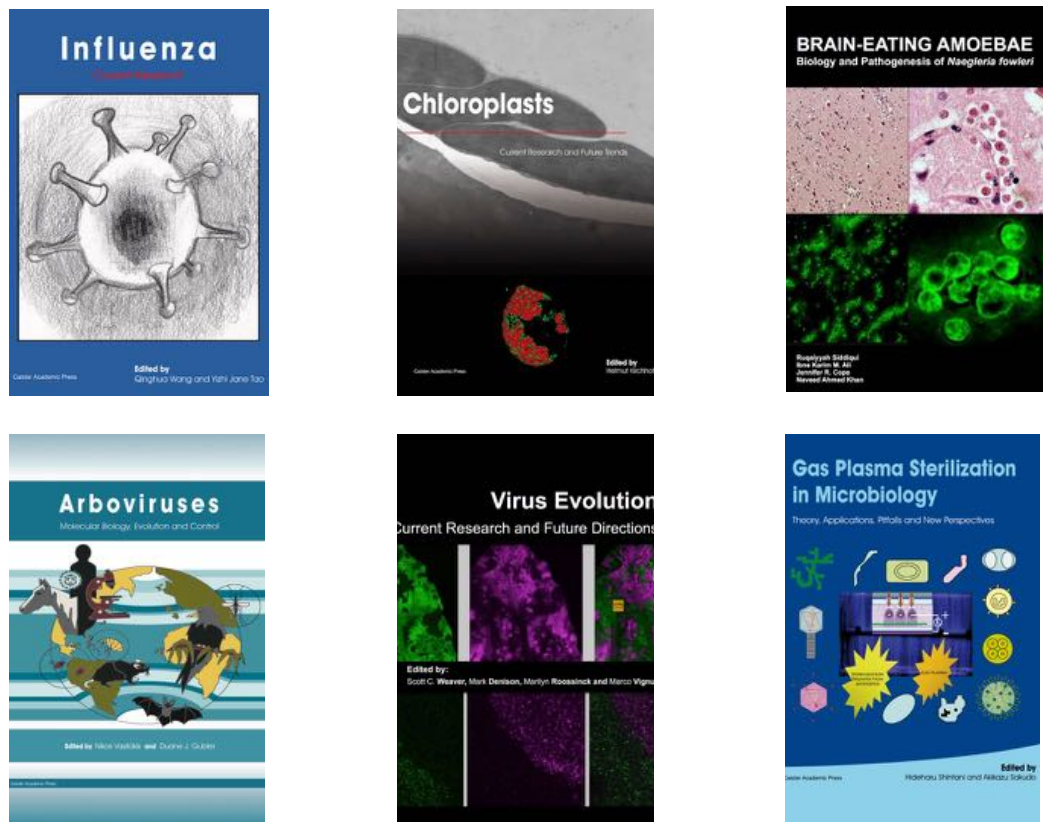

- Climate Change and Microbial Ecology: Current Research and Future Trends

Edited by: J Marxsen (2016)

"impressive" (ASM: Small Things Considered); "written at a high scientific level" (BioSpektrum)

www.caister.com/climate

- Biofilms in Bioremediation: Current Research and Emerging Technologies

Edited by: G Lear (2016)

"describes explicitly the role of biofilms in bioremediation" (Biospektrum); indispensable ... recommended (Biotechnol. Agron. Soc. Environ.) www.caister.com/biorem

- Microalgae: Current Research and Applications

Edited by: MN Tsaloglou (2016)

www.caister.com/microalgae

- Gas Plasma Sterilization in Microbiology: Theory, Applications, Pitfalls and New Perspectives

Edited by: H Shintani, A Sakudo (2016)

"a nice state of the art compilation" (Doodys)

www.caister.com/gasplasma

- Virus Evolution: Current Research and Future Directions Edited by: SC Weaver, M Denison, M Roossinck, et al. (2016) "highly informative ... a pleasure to read" (Microbiol. Today) www.caister.com/virusevol

- Arboviruses: Molecular Biology, Evolution and Control Edited by: N Vasilakis, DJ Gubler (2016)

"a thorough and compelling review ... an outstanding book ... highly recommended" (Am. J. Trop. Med. Hyg.) www.caister.com/arbo

- Shigella: Molecular and Cellular Biology

Edited by: WD Picking, WL Picking (2016)

www.caister.com/shigella

- Aquatic Biofilms: Ecology, Water Quality and Wastewater Treatment

Edited by: AM Romaní, H Guasch, MD Balaguer (2016)

"essential reference book" (Biotechnol. Agron. Soc. Environ.)

www.caister.com/aquaticbiofilms

- Alphaviruses: Current Biology

Edited by: S Mahalingam, L Herrero, B Herring (2016)

"up-to-date review of the field" (Aus. Vet. J.)

www.caister.com/alpha 